\title{
Immunological control of herpes simplex virus infections
}

\author{
Kevin P. Egan • Sharon Wu • Brian Wigdahl • \\ Stephen R. Jennings
}

Received: 14 April 2013 / Revised: 8 July 2013 / Accepted: 17 July 2013 / Published online: 14 August 2013

(C) The Author(s) 2013. This article is published with open access at Springerlink.com

\begin{abstract}
Herpes simplex virus type 1 (HSV-1) is capable of causing a latent infection in sensory neurons that lasts for the lifetime of the host. The primary infection is resolved following the induction of the innate immune response that controls replication of the virus until the adaptive immune response can clear the active infection. HSV-1-specific $\mathrm{CD}^{+} \mathrm{T}$ cells survey the ganglionic regions containing latently infected neurons and participate in preventing reactivation of HSV from latency. The long-term residence and migration dynamics of the T cells in the trigeminal ganglia appear to distinguish them from the traditional memory $\mathrm{T}$ cell subsets. Recently described tissue resident memory $\left(\mathrm{T}_{\mathrm{RM}}\right) \mathrm{T}$ cells establish residence and survive for long periods in peripheral tissue compartments following antigen exposure. This review focuses on the immune system response to HSV-1 infection. Particular emphasis is placed on the evidence pointing to the HSV-1-specific $\mathrm{CD}^{+} \mathrm{T}$ cells in the trigeminal belonging to the $T_{R M}$ class of memory $T$ cells and the role of $T_{R M}$ cells in virus infection, pathogenesis, latency, and disease.
\end{abstract}

Keywords Herpes simplex virus - Tissue resident memory $\mathrm{T}$ cells $\cdot$ Trigeminal ganglia latency $\cdot$ Reactivation $\cdot$ Recurrent disease

\section{Introduction to virus and infection cycle}

Herpes simplex virus (HSV) type 1 (HSV-1) is a ubiquitous human pathogen capable of causing an infection that lasts for the lifetime of the host as a primary, latent, recurrent, or

K. P. Egan $\cdot$ S. Wu $\cdot$ B. Wigdahl $\cdot$ S. R. Jennings $(\bowtie)$

Department of Microbiology and Immunology, and Center for Molecular Virology and Translational Neuroscience, Institute for Molecular Medicine and Infectious Disease, Drexel University College of Medicine, 245 North 15th Street, Philadelphia, PA 19102, USA

e-mail: stephen.jennings@drexelmed.edu persistent infection. The HSV-1 genome is a $152-\mathrm{kbp}$ double-stranded linear DNA genome that encodes for upwards of 84 genes (Roizman et al. 2007). The genome is contained within the nucleocapsid, which is surrounded by a heterogeneous group of proteins collectively designated as the tegument. The tegument and nucleocapsid are surrounded by a lipid envelope studded with glycoproteins that are used to bind to and enter new susceptible cells. HSV-1 is a widespread pathogen that can be found in up to $53 \%$ of the adult population in the United States, with carriage found to be even higher in selected groups of individuals $(\mathrm{Xu}$ et al. 2006). A unique feature of HSV-1 and other human $\alpha$ herpesviruses (HSV type 2 [HSV-2] and varicella zoster virus $(\mathrm{VZV}))$ is the ability to cause a latent infection of sensory neurons innervating peripheral tissues. The latent infection is maintained for the lifetime of the host and can be periodically interrupted by asymptomatic or clinically apparent reactivation events of variable duration and severity. The number of recurrent infections in an individual with HSV is highly variable, whereas reactivation of VZV is seldom observed more than once or twice over the course of a lifetime. The natural history of VZV has been dramatically altered by the availability of vaccines directed at preventing varicella or chickenpox, the primary disease (Shah et al. 2010), and zoster or shingles, the reactivated form of the disease (Oxman et al. 2005). An effective vaccine directed against with HSV-1 or HSV-2 has yet to be delivered to the human population to prevent either primary or reactivated disease or as a therapeutic modality (Chentoufi et al. 2012).

The HSV-1 infection cycle begins when the virus replicates in epithelial cells following transmission to a new uninfected host. HSV-1 glycoproteins $\mathrm{B}(\mathrm{gB})$ and $\mathrm{C}(\mathrm{gC})$ are responsible for virion attachment to host cells by interacting with heparan sulfate proteoglycans (HSPGs) (Shukla and Spear 2001). Filopodia extending out of cells contain high concentrations of HPSGs, and viruses have been shown to travel along filopodia to cell bodies in a process termed virus surfing ( $\mathrm{Oh}$ 
et al. 2010). Cells lacking HSPGs can still be infected by virions due to the ability of $\mathrm{gB}$ to bind to paired immunoglobulin like type 2 receptor alpha (PILR $\alpha$ ) (Satoh et al. 2008). Glycoprotein B is highly conserved and is essential for virion attachment and fusion. Glycoprotein $\mathrm{C}$ is considered nonessential as viruses lacking $\mathrm{gC}$ are still infectious, though they have reduced infection efficiency (Shukla and Spear 2001).

Following binding to the cell surface, the virus enters through fusion at the plasma membrane or endocytic vesicles. Fusion is mediated through glycoprotein $\mathrm{D}(\mathrm{gD})$ interacting with cellular receptors which induces a conformational shift in $\mathrm{gD}$ (Carfí et al. 2001). This conformational change causes the formation of the multiprotein fusion complex which consists of $\mathrm{gD}, \mathrm{gB}, \mathrm{gH}$, and $\mathrm{gL}$ (Campadelli-Fiume et al. 2007). Glycoprotein D is capable of using multiple cellular receptors found on a number of cell types for initiation of fusion. Herpesvirus entry mediator is used by gD for entry of HSV1 into human trabecular meshwork cells (Tiwari et al. 2005). Specific isoforms of 3-O sulfated heparan sulfate is used for entry into primary corneal fibroblasts (Shukla et al. 1999). Nectin-1 is responsible for entry into epithelial cells and, importantly, neuronal cell populations (Shukla et al. 2012; Simpson et al. 2005). Additionally, PILR $\alpha$ has been shown to enable infection of normally resistant cell populations when they are transfected to express PILR $\alpha$ (Satoh et al. 2008). HSV-1 has also been shown to be capable of entering cells through fusion following endocytosis. The mechanism of entry for this pathway has not been fully defined, but it appears that it could be cell type- and/or receptor-specific (Nicola and Straus 2004).

Fusion of the HSV-1 viral envelope with the plasma membrane of susceptible cells delivers the tegument proteins and nucleocapsid into the cytosol of the target cell. Tegument proteins serve to regulate cell processes (Strom and Frenkel 1987), evade the immune system (Sen et al. 2013), and promote transcription of viral genes. Tegument protein VP16 $\left(\mathrm{V}_{\mathrm{MW}} 65\right.$, or an $\alpha$-transinducing factor $[\alpha$-TIF] $)$ associates with host cell factor 1 (HCF1) and octamer-binding transcription factor 1 (OCT 1) to form a transcription factor complex that strongly promotes the transcription of immediate-early (IE) or $\alpha$ viral genes (Gerster 1988). The transcription of HSV-1 genes proceeds in an organized temporal pattern, with $\alpha$ genes being expressed first. The IE gene products serve as activators for the transcription of early or $\beta$ genes, which encode for proteins necessary for replication of viral DNA. Following amplification of the viral genome, the late or $\gamma$ genes, which comprise the virion structural components, are expressed, as previously reviewed (Roizman et al. 2011). Packaged virions are released and spread to nearby uninfected cells, thereby expanding the amount of infectious virus and facilitating the spread of the infection to neighboring epithelial cells. Perhaps more importantly with respect to the natural history of HSV disease, the virus also infects neighboring peripheral sensory neurons during primary infection setting the stage for the establishment of latent infection.

HSV-1 virions bind to and enter axons and travel in a retrograde direction toward the neuronal cell body, as previously reviewed (Smith 2012). After reaching the nucleus of the neuron, the viral genome is translocated from the capsid and docked at the nuclear membrane into the nucleus, where it is thought to circularize in preparation for DNA synthesis. The circular form of the HSV genome has also been shown to be the predominant form of the genome that is maintained during the course of viral latency (Mellerick and Fraser 1987; Su et al. 2002). At the earliest stages of nuclear invasion, there are a number of different viral replication modes that can be followed which have different consequences for the infected neuron. In some cases, genomic activation of IE genes by the tegument transactivator protein VP16, HCF/OCT, and possibly other factors leads to productive infection with synthesis of infectious virions that can cause the death of at least some neurons with the potential for replication and disease in the periphery after release of the progeny virus from neuronal axons in the periphery. However, in some neurons, productive infection may be prevented or aborted by the presence of neuronal nuclear factors that prevent the activation of the promoters and therefore prevent or abort productive replication and send the virus into a latent state (Bloom et al. 2010; Cliffe et al. 2009; Knipe and Cliffe 2008). It has been proposed that some neurons are more susceptible to productive infection whereas some neuronal types might be either reversibly or irreversibly susceptible to viral latency based on the differential presence of regulatory RNAs or regulatory proteins (Bertke et al. 2012, 2011; Yang et al. 2000). The latent infection is characterized as maintenance of the viral genome within the neuron in the absence of production of new infectious virus. Viral gene expression is limited to the latencyassociated transcript (LAT) and possibly the low-level expression of other genes (Feldman et al. 2002; Kramer and Coen 1995; Ramachandran et al. 2010). The protein and/or RNA regulatory factors that guide the virus into latency or that maintain the control of the latent state or initiate reactivation are largely unknown but are beginning to come to light (Camarena et al. 2010; Kim et al. 2012a, b; Thompson and Sawtell 2011). It also is possible that the greater distance the virus must travel to reach the neuronal nucleus, the lower the level of available tegument proteins that would be available for promoting the expression of IE genes once the genome reaches the (Sears et al. 1991) nucleus of the infected neuron. An additional mechanistic theory centers on neuronal sequestration of HCF1 in the cytoplasm instead of the nucleus, in which case this factor would not be available to interact with VP16 in the nucleus to enhance transactivation of early promoters and facilitate productive replication (Kristie et al. 1999). A combination of viral and host cell factors is probably responsible for the establishment and maintenance of latent 
infection of neurons. The latent phase is likely of evolutionary benefit to the virus as it maintains a stable reservoir of viral genomic information from which periodic reactivations emanate and allows for transmission of infectious virus to new hosts over the lifetime of the infected host.

Following selected stimuli, viral gene expression has been shown to be enhanced, with infectious virus production first in the ganglia and later at peripheral sites. At least a fraction of the newly made capsids in the neuronal nucleus are thought to travel anterograde to the axonal terminal with release into the periphery (Smith et al. 2001). Reactivation of the virus can often be asymptomatic, but replication in peripheral epithelial cells can also lead to symptomatic disease. Herpes labialis is caused by the formation of vesicular lesions resulting from replication in epithelial cells. Rupture of these lesions causes spread of the virus to different anatomical regions or transmission to new hosts. Usually, the disease is self-limiting in immunocompetent individuals; however, serious disease can occur in immunocompromised individuals (Rowley et al. 1990). Replication in corneal epithelial cells results in corneal scarring and can lead to herpes stromal keratitis, a leading cause of blindness in the United States (Kaye and Choudhary 2006). HSV-1 infection of the brain is rare but can lead to fatal herpes encephalitis in the absence of early therapeutic intervention (Brady and Bernstein 2004).

\section{Role of the immune system in HSV-1 infection}

The immune system plays an important role in limiting HSV-1 replication during primary infection and in maintaining the viral genome in a latent state for prolonged periods in the absence of infectious virus production and clinical symptoms. Replication in peripheral epithelial cells causes production and release of type 1 interferons that activate cells of the innate immune system. Activated macrophages secrete interferons and cytokines, which recruit and activate additional cells of the innate immune response to the site of infection. Type 1 interferons induce an antiviral state in uninfected epithelial cells that makes it harder for the virus to replicate in these cells as well. Recruited neutrophils induce apoptosis in infected cells and phagocytose dying cells. Activated natural killer (NK) cells release interferon- $\gamma$ and granzymes A and B, which induce apoptosis in infected cells. Dendritic cells (DCs) secrete proinflammatory cytokines, take up antigen, and present viral peptides to cells of the adaptive immune system. The innate immune response limits viral replication in the periphery and presents antigen to the naïve lymphocytes to activate the adaptive immune response. It appears that the principal role of B cells in the immune response to HSV-1 infection is not to produce neutralizing antibodies but instead to present antigen and secrete cytokines (Deshpande et al. 2000). Activated $\mathrm{CD} 4^{+}$and $\mathrm{CD} 8^{+} \mathrm{T}$ cells play a pivotal role in clearing the primary infection. Additionally, $\mathrm{CD} 8^{+} \mathrm{T}$ cells are important for maintaining the virus in the latent state, as will be discussed below (Fig. 1).

Detection of HSV-1 infection occurs initially within the infected peripheral epithelial cells. Viral pathogen-associated molecular patterns (PAMPs) are detected by pattern recognition receptors (PRRs) within infected cells and induce intracellular signaling, which results in cytokine release and interferon production. Recently, the detection of HSV-1 PAMPs by cellular PRRs has been reviewed extensively (Melchjorsen 2012; Paludan et al. 2011). Extracellular HSV-1 is detected as a result of $\mathrm{gD}$ binding to PRRs on the surface of the host cell prior to membrane fusion (Ankel et al. 1998; Kim et al. 2012a, b). Intracellular PAMPs such as viral nucleic acids are detected either in the cytoplasm or in endosomal compartments.

Viral nucleic acids are the primary PAMPs detected by HSVinfected cells and readily induce expression of proinflammatory cytokines and interferons. The HSV-1 genome is composed of double-stranded DNA that contains unmethylated $\mathrm{CpG}$ motifs (Lundberg et al. 2003). CpG motifs are detected by the Toll-like receptor 9 (TLR-9) embedded in the membrane of endosomal compartments. How HSV-1 DNA is detected within endosomal compartments is not definitively known, but the virus is capable of infecting cells through endocytosis in addition to membrane fusion (Rahn et al. 2011). HSV-1 DNA from infected cells can also be endocytosed, where it can be detected by TLR-9 in plasmacytoid DCs and B cells (Bosnjak et al. 2012; Pollara et al. 2003). Cytoplasmic DNA sensors detect HSV-1 DNA not found in endosomal compartments. DNA-dependent activator of interferon regulatory factors (DAI), interferon- $\gamma$-inducible protein 16 (IFI16), DXH9, and DXH36 detect DNA motifs in the cytoplasm. IFI16 has recently been shown to be able to activate and maintain normal levels of interferon in the absence of TLR signaling in corneal epithelial cells (Conrady et al. 2012). DXH9 and DXH36 detect DNA-containing CpG motifs and activate $\mathrm{NF}-\mathrm{\kappa B}$ and interferon regulatory factor 7 , respectively.

Although the HSV-1 virion contains a DNA genome, replication intermediates can be detected by PRRs specific for double-stranded RNA (dsRNA) (Weber et al. 2006). Endosomal dsRNA is detected by TLR-3, which is expressed in many cell types, and expression can be induced by type 1 interferons (Tissari et al. 2005). The importance of TLR-3 activation in HSV-1 infection has been illustrated by children with genetically deficient TLR-3, who have greater susceptibility to herpes encephalitis (Guo et al. 2011; Herman et al. 2012; Zhang et al. 2007). Recently, Lafaille et al. (2012) demonstrated that TLR-3deficient CNS cells have reduced intrinsic innate immune activation. Taking dermal fibroblasts from TLR-3-deficient patients and generating induced pluripotent stem cells of neuronal lineage, they demonstrated that TLR-3-negative neurons and oligodendrocytes induce fewer type 1 interferons in response to HSV- 


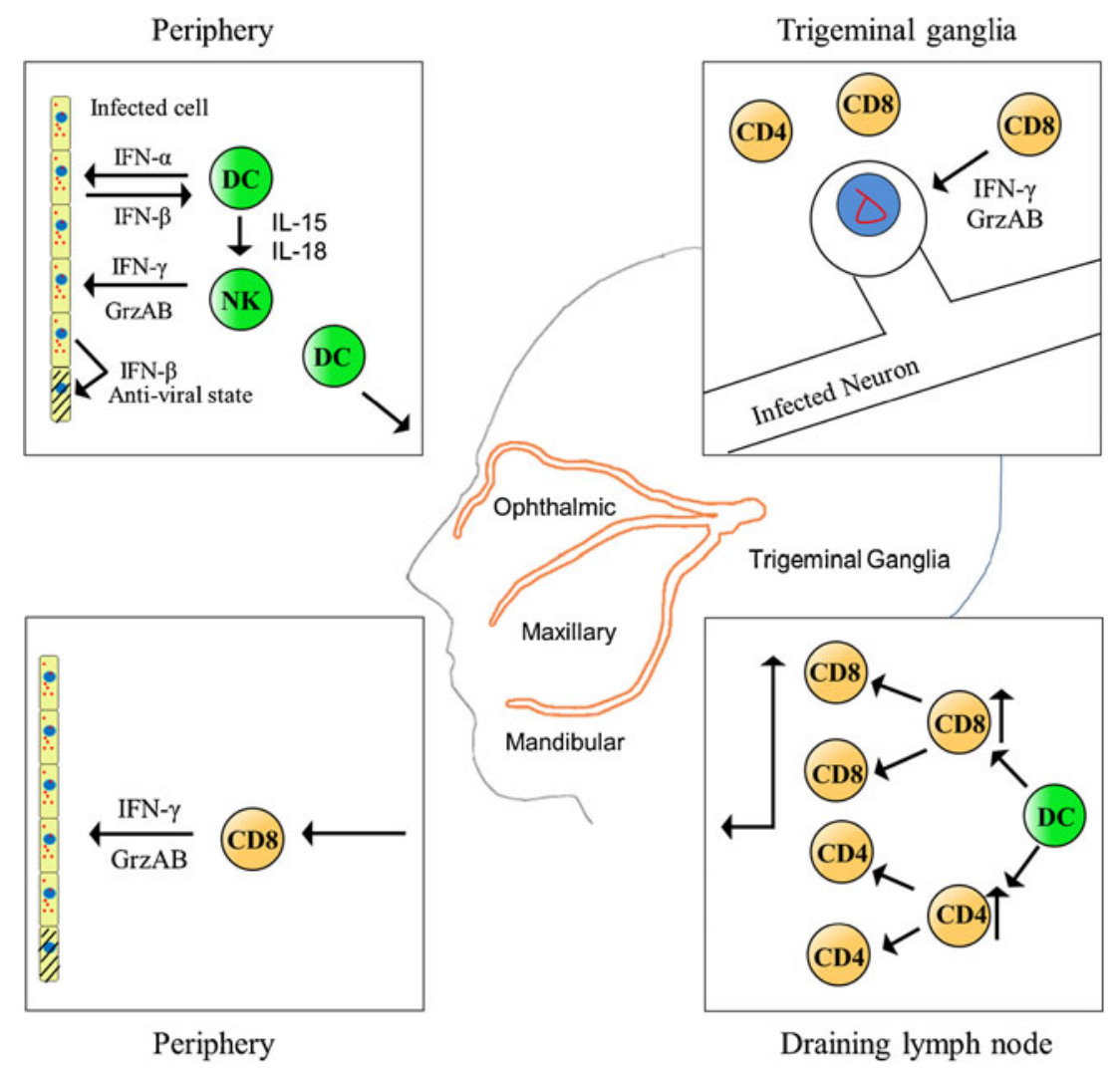

Fig. 1 HSV-1 immune responses. Productive HSV-1 infection occurs in epithelial cells in the oral mucosa. Released virions infect neighboring cells and innervating sensory neurons. The virus travels retrograde to establish latent infection in the trigeminal ganglia. HSV-1 infection is detected in epithelial cells and induces production of interferon- $\beta$ (IFN$\beta$ ). IFN- $\beta$ activates innate immune cells, which in turn secrete IFN- $\alpha$. Type 1 IFNs induce the antiviral state in an autocrine fashion in the

1 infection. Cytosolic viral RNA intermediates are detected through retinoic acid inducible gene (RIG)-like receptors (RLRs) that contain DExD/H box helicase domains (Kato et al. 2008). RIG-I and MDA-5 (melanoma differentiation-associated gene 5) recognize short dsRNA (Schlee et al. 2009) and longer dsRNA higher-order structures (Pichlmair et al. 2009), respectively. RLR signaling induces IRF-3 and NF- $\mathrm{KB}$ activation, leading to type 1 interferon production and proinflammatory cytokine production.

The interferon-induced antiviral state is important for limiting the immediate viral replication in susceptible cells of the periphery. The difference between the severe response observed in $\mathrm{BALB} / \mathrm{c}$ mice and the controlled response in C57BL/6 mice has recently been attributed to the enhanced innate response present in the $\mathrm{C} 57 \mathrm{BL} / 6$ mice (Sheridan et al. 2009). Interferon signaling leads to expression of interferonstimulated genes ribonuclease L (RNAse L), protein kinase RNA-activated (PKR), and 2'-5' oligoadenylate synthetase. These antiviral enzymes accumulate in cells in response to interferon binding and have been shown to be ready to act upon signs of virus infection. PKR phosphorylates EIF- $2 \alpha$, a producing cell and in surrounding epithelial cells. Interleukin-18 (IL18) released from dendritic cells (DCs) activates natural killer (NK) cells that secrete IFN- $\gamma$ and granzymes A and B (GrzAB). DCs engulf HSV-1 virions and travel to the draining lymph node where they activate naïve $\mathrm{B}$ and T cells. Activated T cells travel back to the site of primary infection and the trigeminal ganglia, where they surround infected neurons and prevent replication via secretion of IFN- $\gamma$ and granzymes A and B

necessary protein for protein translation to proceed. Inhibition of protein translation prevents viral replication and causes viral mRNA transcripts to accumulate. Viral mRNA transcripts are actively degraded by RNAse L, which has been shown to be activated in response to dsRNA and $2^{\prime}-5^{\prime}$ oligoadenylate synthetase. These mediators of translational inhibition are activated in response to PAMPs present within infected cells and thus do not necessarily prevent translation in uninfected cells.

Primary recruited immune cell mediators include monocytes, neutrophils, DCs, and NK cells. Attracted neutrophils secrete the antiviral molecule tumor necrosis factor- $\alpha$ (TNF- $\alpha)$, which can induce apoptosis in infected epithelial cells through a caspase-8-dependent pathway. Neutrophils also phagocytose necrotic and apoptotic epithelial cells. Monocytes attracted to the area differentiate into tissue macrophages and phagocytose released virions and apoptotic cells. Macrophages are professional antigen-presenting cells (APCs) that release proinflammatory cytokines and present viral peptides to cells of the adaptive immune response. Macrophages in peripheral tissue sites where initial infection 
occurs (Cheng et al. 2000; Mott et al. 2007) and in the trigeminal ganglia (Kodukula et al. 1999) serve to limit viral replication until the adaptive immune system can be activated. Macrophages secrete proinflammatory cytokines such as TNF- $\alpha$, interleukin-6 (IL-6), RANTES ("regulated on activation, normal $\mathrm{T}$ cell expressed and secreted"), type 1 interferons, and nitric oxide (NO). NO production is initiated by the enzyme inducible nitric oxide synthase (iNOS), which is activated from interferon- $\gamma$ released from $\gamma \delta-\mathrm{T}, \mathrm{NK}, \mathrm{CD} 4^{+} \mathrm{T}$, and $\mathrm{CD}^{+} \mathrm{T}$ cells. NO released from macrophages has been shown to significantly reduce HSV-1 levels when treating in vitro macrophage cultures. When iNOS is inhibited in mouse models, virus replication increases in the trigeminal ganglia (Kodukula et al. 1999).

Dendritic cells play an important role in the immune response by activating NK cells at the site of infection and acting as APCs to activate cells of the adaptive immune system. HSV-1 PAMPS activate immature DCs which differentiate and mature. Mature DCs can activate other immature DCs through the release of type 1 interferons (Pollara et al. 2004). Mature DCs travel to the draining lymph node, where viral peptides are presented to naive $\mathrm{B}$ and $\mathrm{T}$ cells for activation. Viral peptides can also be presented in the context of HSV-1 infection of DCs through a cross-presentation pathway. HSV-1 infected DCs are unable to mature but are still capable of secreting cytokines that activate uninfected DCs; infected DCs are also induced to undergo apoptosis via downregulation of C-FLIP (cellular FLICE-like inhibitory protein) (Kather et al. 2010). Infected apoptotic DCs are taken up by activated DCs which process the antigen and present peptides to cells of the adaptive immune system (Bosnjak et al. 2012). An additional role of DCs is to secrete IL-18, which is necessary for the activation of NK cells (Kassim et al. 2009; Reading et al. 2007). Mice lacking DCs exhibit increased HSV-1 neurovirulence during the course of infection based primarily on the limited activation of $\mathrm{NK}, \mathrm{CD}^{+} \mathrm{T}$, and $\mathrm{CD}^{+} \mathrm{T}$ cells (Kassim et al. 2006).

Natural killer cells are crucial to controlling HSV-1 virus levels in the periphery by directly inducing cell death in infected epithelial cells (Grubor-Bauk et al. 2008). Like $\mathrm{CD} 8^{+} \mathrm{T}$ cells, NK cells contain preformed granules of perforin, granzyme A, and granzyme B. HSV-1 infection reduces major histocompatibility complex (MHC) class 1 expression in epithelial cells by the action of ICP47, a viral immediate-early gene, which blocks loading of TAP (transporter associated with antigen presentation) and presentation of viral peptides through MHC class 1 (York et al. 1994). The reduction in MHC class 1 is a signal that NK cells use to target virus-infected cells (Ravetch 2000). Recently, it has been shown that NK cells can also be activated by HSV-1 gD binding to TLR-2 on the surface of NK cells (Kim et al. 2012a, b). Mice suffer greater mortality in response to HSV1 infection when NK cells are depleted (Grubor-Bauk et al.
2008; Williams et al. 1998), or NK survival factor IL-15 is inhibited in the context of HSV-2 infection (Ashkar and Rosenthal 2003).

\section{$\mathrm{CD8}^{+} \mathrm{T}$ cell response}

Antiviral $\mathrm{CD}^{+} \mathrm{T}$ cells exert their effector function through secretion of interferon- $\gamma$, TNF- $\alpha$, perforin, and granzymes after engaging antigens in the context of MHC class I molecules of the target cells. $\mathrm{CD} 8^{+} \mathrm{T}$ cells induce apoptosis in infected cells by releasing preformed granules or through death receptor signaling. The granules contain perforin, granzymes, and granulysin, which work together to enter the target cell and induce apoptosis. Perforin has been shown to polymerize on the target cell membrane forming a pore, allowing entry of granzymes and granulysin (Liu et al. 1995; Voskoboinik et al. 2005). However, in the absence of perforin, granzyme B can be internalized by endocytosis into the target cell, possibly by interacting with the mannose-6-phosphate receptor (Motyka et al. 2000). Although perforin and granzymes are both internalized and released into the cytoplasm of the target cell, perforin was found to be essential for inducing apoptosis (Froelich et al. 1996). Granulysin, a small cationic protein, is present in the lytic granules of NK cells, NKT cells, helper $\mathrm{T}$ cells, and cytotoxic $\mathrm{T}$ lymphocytes (CTLs) (Latinovic-Golic et al. 2007). This process has been shown to cause target cell lysis when it interacts with negatively charged cell membrane proteins. Granulysin can also induce apoptosis through the release of cytochrome C (Latinovic-Golic et al. 2007).

Granzymes A and B belong to the serine-protease family and can induce apoptosis in caspase-independent and caspasedependent ways (Waterhouse et al. 2006b). Granzyme A acts in a caspase-independent way to induce apoptosis by cleaving single-stranded DNA and by hydrolyzing histone proteins (Fan et al. 2003; Mueller et al. 2003). It can also cleave the IL-1 $\beta$ propeptide into the active IL-1 $\beta$ (Irmler et al. 1995; Nicola et al. 2005). Granzyme B can induce apoptosis in a caspase-dependent manner by activating procaspase 3 directly or by increasing the permeability of mitochondria and cleaving the Bcl-2 interacting domain (Bid) protein (Metkar et al. 2003; Pinkoski et al. 2001).

$\mathrm{CD}^{+} \mathrm{T}$ cells also respond to viral infections through the production and release of interferon- $\gamma$. Interferon- $\gamma$ promotes presentation of viral peptides, inhibits viral replication, arrests the cell cycle, and promotes the th1 immune response. Interferon- $\gamma$ induces expression of immunoproteosomal subunits (Belich et al. 1994; Groettrup et al. 1996; Kelly et al. 1991) which can enhance processing of viral peptides for loading into the MHC class 1 (Sijts and Kloetzel 2011). Interferon- $\gamma$ also enhances the class 2 antigen presentation pathway, increasing expression of MHC 2 molecules in both 
professional and non-professional cells (Handunnetthi et al. 2010). Cells exposed to IFN- $\gamma$ inhibit viral replication through expression of antiviral genes like PKR which inhibits translation within the cell (Meurs et al. 1990). Additional effects of IFN- $\gamma$ include increased expression of cyclin-dependent kinase inhibitors p21 (Xaus et al. 1999) and p27 (Harvat et al. 1997) to arrest cell cycle progression. Interferon- $\gamma$ also skews the immune response by promoting differentiation of naïve $\mathrm{T}$ cells into Th1 cells (Yoshida et al. 1994).

Death receptor signaling is a caspase-8-dependent process of inducing apoptosis. CD95 ligand on the surface of $\mathrm{CD} 8^{+} \mathrm{T}$ cells binds with the CD95 receptor to initiate signaling. The CD95 receptor contains a death effector domain that is a binding site for procaspase 8 . Procaspase 8 is cleaved upon binding to the death effector domain, forming the active caspase 8 . Activated caspase 8 can then directly cleave procaspase 3 , the primary downstream mediator of apoptosis. Both granzyme B and activated caspase 8 can cleave Bid to the truncated form (tBid). The activated tBID can induce release of cytochrome $\mathrm{C}$ from the mitochondria and induce apoptosis through the intrinsic pathway (Korsmeyer et al. 2000; Waterhouse et al. 2006a, b).

The mechanisms described above allow virus-specific CTLs to efficiently eliminate virus-infected cells from the body by inducing apoptosis and thereby limit the virus capacity to produce new virions. This mechanism of clearance has been shown to be an effective response to viruses in peripheral tissues where apoptotic cells can be replaced by mitogenic precursors. However, the neurons that reside in the nervous system are nonmitogenic. This presents a problem for the body wherein clearance of virus-infected neurons cannot be replaced (Okouchi et al. 2007). Indeed it appears that granulemediated apoptosis is attempted by $\mathrm{CD} 8^{+} \mathrm{T}$ cells to control the latent HSV-1 infection; however, latently infected neurons are rarely induced into apoptosis.

Virus-specific $\mathrm{CD}^{+} \mathrm{T}$ cells infiltrating into the trigeminal ganglia are capable of preventing reactivation and maintaining HSV-1 in the latent state (Liu et al. 2000). CTLs infiltrate into the trigeminal ganglia, surround infected neurons, form immunological synapses, and release preformed granules that can be detected within target cells. Yet these molecules do not induce apoptosis of latently infected neurons (Knickelbein et al. 2009). Granzyme A was shown to act in a noncytolytic capacity to limit the spread of HSV-1 to other neurons, though the mechanism is unknown (Pereira et al. 2000). Granzyme B, instead of directly cleaving the normal target procaspase 3, instead cleaves the IE protein ICP4 (Knickelbein et al. 2009). ICP4 is necessary for efficient reactivation of the virus, and cleavage by granzyme $\mathrm{B}$ is a noncytolytic mechanism by which CTLs can react to viruses and virus-infected neurons and thereby control reactivation.

Additionally, interferon- $\gamma$ produced by the CTLs plays a pivotal role in preventing reactivation. Decman et al. (2005) demonstrated that interferon- $\gamma$ is capable of reducing expression of ICP0 promoters, possibly by global regulation of transcription factors. Carr et al. (2009) showed that transgenic expression of interferon- $\gamma$ in the trigeminal ganglia reduced HSV-1 reactivation in mouse models when exposed to ultraviolet light. Another important role of interferon- $\gamma$ centers on increasing the expression of the heavy and light chain of MHC class I molecules in addition to chaperones and other proteins that help assemble the peptide-MHC class I complex (Wallach et al. 1982). Interferon- $\gamma$ induces expression of MHC class 1 in neurons that normally lack MHC class 1 expression (Wallach et al. 1982). Interestingly, Chentoufi et al. (2011) showed that expression of LAT in neuroblastoma cell lines also increased expression of MHC class I molecules. To counter increased presentation from upregulated MHC class I expression, the HSV-1 IE protein ICP47 interacts with the TAP proteins and prevents import of antigenic peptides into the endoplasmic reticulum (Oosten et al. 2007). This inhibits display of HSV-1 antigen on the surface of the neurons. One study has suggested that ICP47 activity is required for HSV-1 to infect neuronal cells (Burgos et al. 2006). An interesting effect of the mouse model of HSV-1 latency is that ICP47 from human viruses does not efficiently interact with the mouse TAP, the effect being that HSV peptides are efficiently displayed. This may be the reason that mice with latent HSV infection, unlike humans, do not exhibit spontaneous reactivations of virus (Feldman et al. 2002). To investigate the effect of TAP and MHC Class 1 inhibition by viral proteins on reactivation, Orr et al. (2008) generated recombinant HSV-1 virus which expressed the murine cytomegalovirus gene m152 (MCMV m152). The MCMV m152 gene has been shown to be capable of inhibiting MHC class 1 export and has also been shown to decrease expression on the cell surface (Tomas et al. 2010). When mice were infected with the recombinant HSV-1, they exhibited increased virus reactivation from latency. However, this model does not reflect spontaneous reactivation as still relies on UV light to stimulate reactivation.

\section{Latent HSV-1 modulation of apoptosis}

Apoptosis is the preferred method that the body uses to eliminate viral infections. This pathway leads to programmed cell death characterized by DNA fragmentation and membrane blebbing, which will be taken up by local immune phagocytes. By inducing cell death, infected cells and the viruses contained within are removed. Most cells removed via apoptosis are capable of being replaced by stem cell precursors, and thus elimination of the infected host cell is a favorable mechanism of limiting viral disease. This process in combination with the antiviral state induced by interferon signaling is the primary method of limiting viral replication in the body and clearing viral infections (Benedict et al. 2002). 
Apoptosis can be triggered in multiple ways that work through a set of proteases called caspases. These mediators of cell death are synthesized as inactive precursors that must in turn be cleaved in order to be activated. Proapoptotic stimuli lead to cleavage of procaspase to caspase, which then proceed to cleave their own substrates in turn. The extrinsic pathway can be activated by a variety of external factors such as cytokines, toxins, or ligand binding to death receptors on the cell surface. The intrinsic apoptosis pathway is triggered by cell stress factors within, such as viral proteins, DNA damage, and oxidative stress, leading to dimerization of proapoptotic molecules on the surface of the mitochondria. This forms a dimer through which cytochrome $\mathrm{C}$ is released into the cytoplasm. Cytoplasmic cytochrome $\mathrm{C}$ associates with Apaf1 to activate procaspase 9 . Activated caspase 9 complexes with Apafl and cytochrome $\mathrm{C}$ to form the apoptosome, which efficiently cleaves and activates procaspases 3 and 7. Both of these pathways activate a different set of caspases, which proceed to clean downstream targets. These pathways converge on the activation of procaspase 3 , which can also be cleaved directly from its precursor from CTL-released granzyme B. Activated caspase 3 leads to chromatin condensation, DNA fragmentation, and the membrane blebbing characteristic of apoptosis, which has been reviewed previously (Elmore 2007; Hengartner 2000).

Herpesviruses produce numerous antiapoptotic factors aimed at delaying or preventing apoptosis to allow for maximal number of infectious virions to be produced. Studies performed with specific null mutants have revealed that ICP4 (Leopardi and Roizman 1996), ICP27, Us3 (Aubert et al. 2006; Jerome et al. 1999), gD (Sciortino et al. 2008), gJ (Jerome et al. 2001), and LAT all have antiapoptotic functions in vitro, though the mechanism is not fully understood for all of them. Recent data suggests cathepsins are involved ICP4- and Us3-mediated inhibition of apoptosis (Peri et al. 2011). Antiapoptotic gene transcription in productively infected epithelial cells has been shown to allow the virus to evade apoptosis, and the cell dies from damage induced by viral replication. The LAT intron is the predominant transcript that can be recovered from latently infected neurons and conveys resistance to apoptosis. Although not absolutely required for establishment of latency, it does play an important role in maintenance and reactivation of latency, in addition to the antiapoptotic effects associated with these RNAs (Bloom 2004).

The antiapoptotic effects derived from LAT in latently infected neurons have not been fully elucidated. The unstable 8.3-kb primary LAT is processed to form a stable 2.0- or 1.5$\mathrm{kb}$ intron (Wagner et al. 1988). HSV-1 LAT null mutants confer decreased protection from cold shock-induced apoptosis (Carpenter et al. 2007). Using specific HSV-1 deletion mutants, Branco and Fraser (2005) localized the antiapoptotic function in the first $1.5-\mathrm{kb}$ region following the LAT promoter. Granzyme B-mediated apoptosis via direct cleavage of procaspase 3 was inhibited by LAT expression (Jiang et al. 2011). LAT has also been shown to inhibit caspase-8-dependent apoptosis induced through death receptor binding (Jin et al. 2010). LAT upregulated expression of the prosurvival protein AKT, which prevented the intrinsic apoptotic pathways initiated within cells (Fig. 2) (Li et al. 2010; Manning and Cantley 2007).

The LAT sequence does contain eight putative open reading frames (ORF) that could encode for antiapoptotic proteins; however, HSV-1 LAT-associated proteins have not been isolated (Drolet et al. 1998a, b). There is circumstantial evidence for LAT-associated proteins within latent infections. Henderson et al. (2009) generated synthetic peptides from the LAT ORF sequences and injected these into rabbits to generate antisera against the peptides. Antisera from two of the peptide sequences bound to protein with neuronal cell cultures. Additionally, immunohistochemistry staining of latently infected trigeminal neurons was also positive utilizing these antisera. However, the role of LAT-associated proteins is still controversial. The structure, abundance, and activity of these proteins have not been thoroughly investigated; it is possible they may play a role in inhibiting apoptosis of infected neurons, but there will need to be further studies to establish this functional connectivity.

An additional mechanism of antiapoptosis activity could lie in the encoding of viral microRNA within the LAT (Jurak et al. 2012). Because of the compact nature of viral genomes in which viruses must package everything they need for productive infection, the encoding of microRNAs in nontranscribed regions and untranslated regions of exons can provide important regulatory elements at the transcriptional level (Boss and Renne 2010; Gottwein and Cullen 2008; Skalsky and Cullen 2010). Using deep sequencing analysis of postmortem latently infected trigeminal ganglia; Umbach et al. (2009) identified seven miRNAs encoded by the HSV-1 LAT, all of them contained within the unstable $6.3-\mathrm{kb}$ exon. These miRNAs have been recovered from postmortem human trigeminal tissues, demonstrating their presence in human HSV-1 infections. The targets for all of the miRNAs have not yet been identified, but miR-H 2 has been demonstrated to target ICP0 and miR-H6 targets ICP4 (Umbach et al. 2008). Recently, it has been shown that mutation of these miRNAs decreases replication of HSV-1 within neurons but has no effect on replication within fibroblasts (Flores et al. 2013). ICP0 and ICP4 are potent activators of the $\beta$ genes and are necessary for reactivation. Additionally, ICP0 expression can induce apoptosis through damage of cellular structures (Sanfilippo and Blaho 2006). The LAT-encoded miRNAs are contained outside of the vital first $1.5-\mathrm{kb}$ region, which is necessary for protection from apoptosis, so it is unlikely these are the main mechanism involved in the inhibition of apoptosis. However, by regulating viral gene transcription, miRNAs can help maintain the virus in a latent state within neurons and prevent expression of proapoptotic genes. Similar to the miRNAs, LAT encodes two small RNAs (sRNAs). LAT 


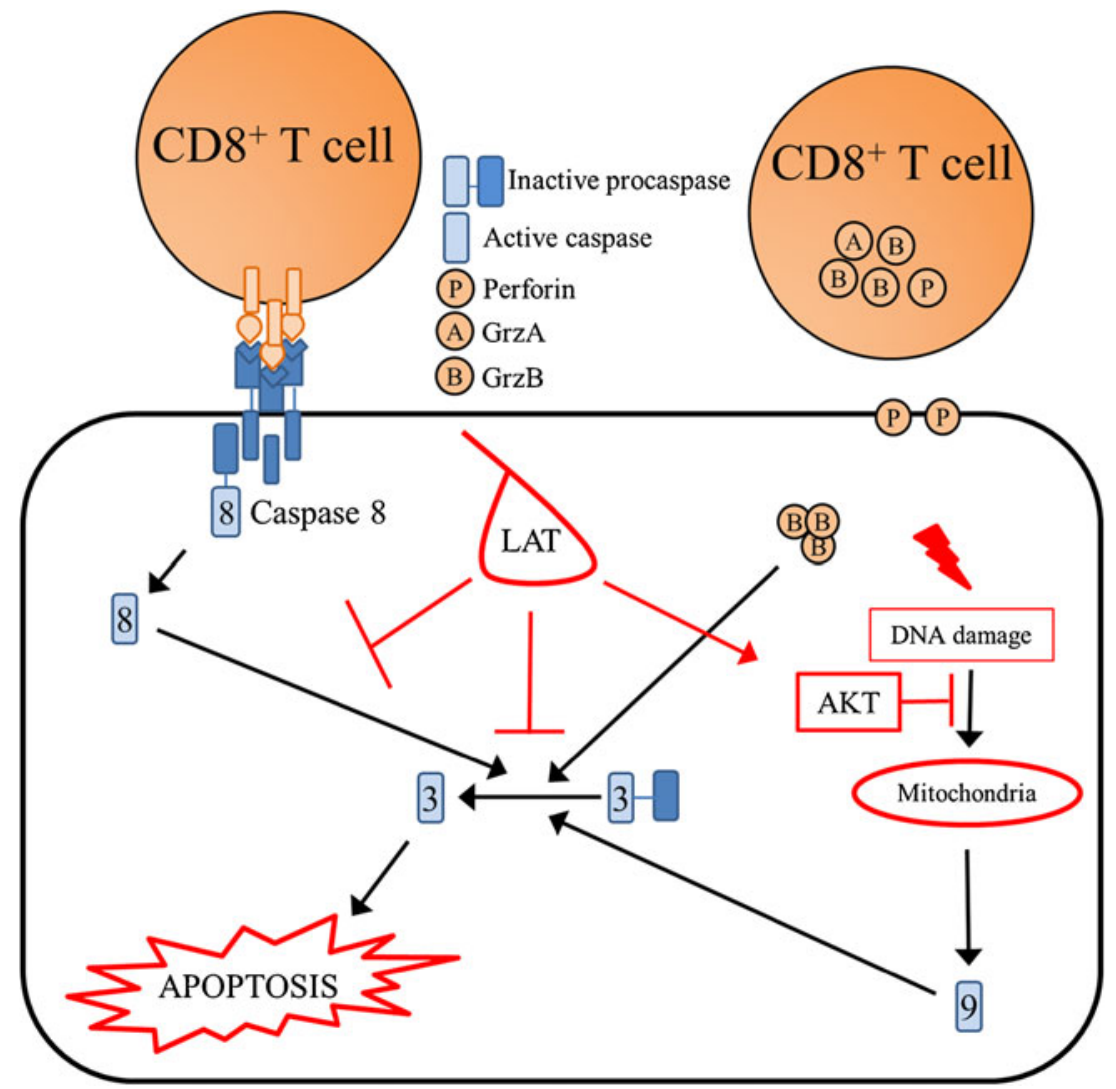

Fig. 2 Expression of latency-associated transcript (LAT) inhibits extrinsic and intrinsic apoptotic pathways. The extrinsic pathway involves proapoptotic triggers provided by activated immune cells. Virus-specific $\mathrm{CD} 8^{+} \mathrm{T}$ cells induce apoptosis by death receptor binding. CD95 ligand binding causes the formation of the death-induced silencing complex, which binds and activates procaspase 8 . Activated caspase 8 activates procaspase 3, which leads to apoptosis. LAT expression is capable of inhibiting the caspase-8-dependent pathway, but the mechanism is unknown. $\mathrm{CD}^{+} \mathrm{T}$ cells releasing preformed granules induce apoptosis by

sRNA2 appears to hybridize to the ICP4 transcript and reduce its expression. Additionally, sRNA1 and sRNA2 act synergistically to inhibit apoptosis induced by cold shock (Shen et al. 2009). The mechanisms by which LAT prevents apoptosis are not yet known, but LAT appears to promote the latent state through viral gene regulation by miRNAs and sRNAs encoded within LAT (Fig. 3).

In contrast to latently infected neurons, productively infected cells in the periphery undergo cell death. Peripheral epithelial cells are susceptible to lytic infection leading to necrosis during productive HSV-1 replication. Other cell types including monocytes and DCs can be induced to initiate apoptosis from both intrinsic proapoptotic stimuli from the virus and from exogenous signals from immune cells (Mastino et al. 1997; Peri et al. 2011). In order to definitively identify which cells are susceptible to apoptosis, Esaki et al. (2010) exposed mice to HSV-1 and HSV-2 using three different inoculation techniques and collected various tissues for HSV-1 antigen staining and apoptotic markers. They found that cells direct cleavage of procaspase 3. Perforin forms a pore on the surface of target cells and allows entry of granzymes A and B (GrzA and GrzB). Granzyme B cleaves and activates procaspase 3, leading to apoptosis. LAT inhibits this pathway by inhibiting granzyme B from activating procaspase 3 . The intrinsic apoptotic pathway is initiated by dimerization of proapoptotic molecules on the surface of the mitochondria. Released cytochrome $\mathrm{C}$ associates with APAF1 and activates procaspase 9. Activated caspase 9 activates procaspase 3. Expression of LAT activates AKT, which prevents the accumulation of proapoptotic molecules

such as those of the corneal epithelium and neurons in the CNS are sensitive to induction of apoptosis when infected by HSV-1. They also found that cells within the trigeminal ganglia, although susceptible to HSV-1 infection, were not apoptotic. These results fit well with previous experiments that have shown that corneal epithelia cells from both animal models and humans undergo apoptosis when infected with HSV-1 (Stuart et al. 2004). However, this has been challenged by Miles et al. (2007), who demonstrated that, although apoptosis is induced during productive infection of corneal epithelial cells, HSV-1 is capable of inhibiting the later stages of apoptosis.

\section{Maintenance of latency requires careful balance of factors}

During neuronal latency, a careful balance is established to maintain the virus in the latent state. The contributors to this balance include the neuronal environment, LAT, and the CD8 ${ }^{+}$ $\mathrm{T}$ cells surrounding the neurons. During latency, the LAT 


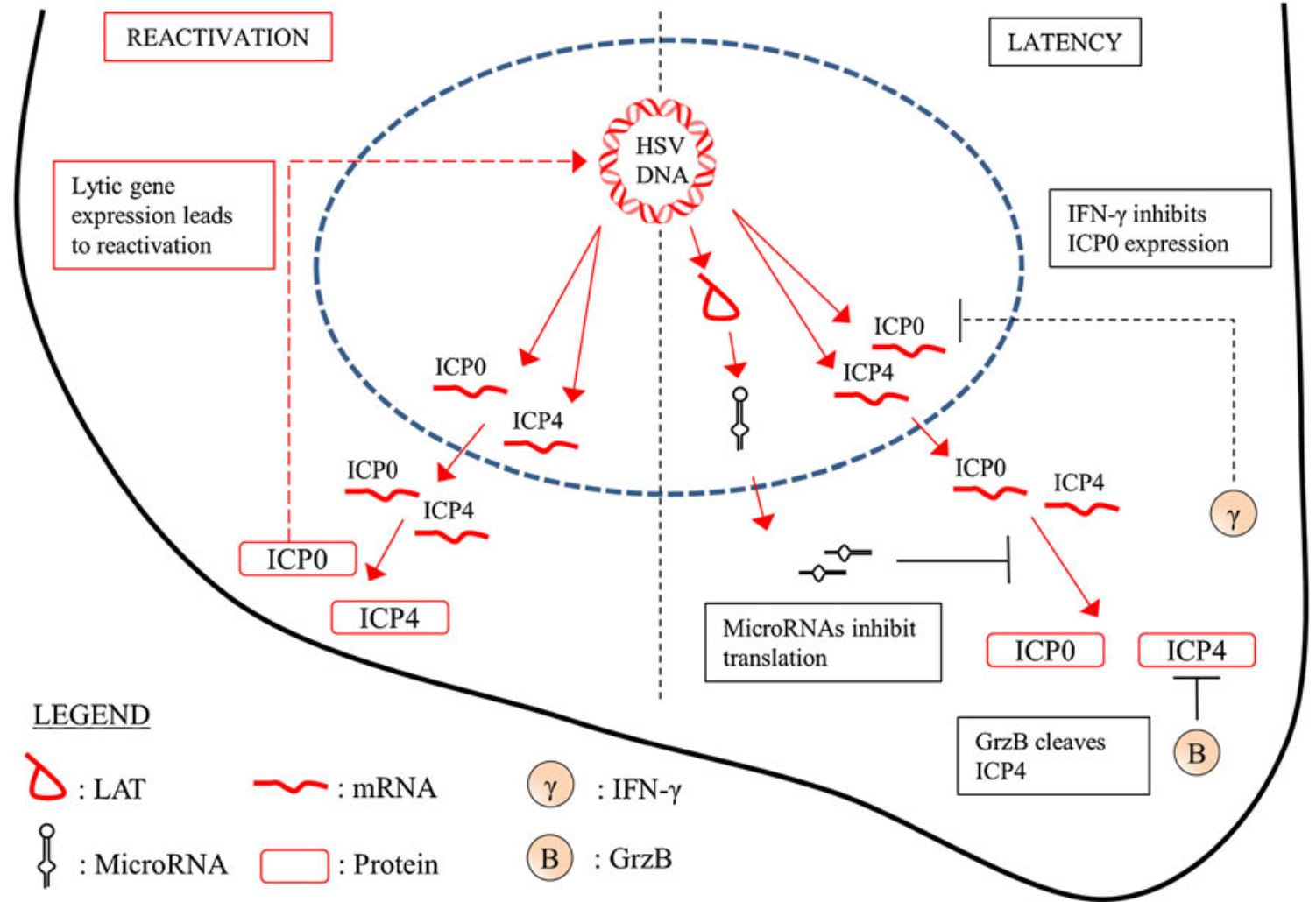

Fig. 3 Small noncoding RNAs in the latency-associated transcript (LAT) gene promote latency. Low-level expression of lytic genes ICPO and ICP4 could lead to spontaneous reaction. The LAT gene encodes two different small noncoding RNA species that prevent low-level ICPO and ICP4 expression. The LAT gene encodes seven microRNAs (miRNAs) that have been confirmed in vivo. Of these, two miRNAs, miR-H2 and miR-H6, have confirmed inhibitory effects on ICP0 and ICP4 protein

intron is the predominant transcript that is made from the viral genome (Wagner et al. 1988). There is evidence, however, of low-level lytic gene expression despite the presence of repressive chromatin modifications (Ramachandran et al. 2010). It has been suggested that, in neuronal cultures, low-level gene expression is required for the production of VP16, a $\gamma$ gene. Once VP16 has been made, the VP16 transcription complex can form and bind to the lytic gene promoters, leading to production of infectious virions (Kim et al. 2012a, b). It is this low-level gene expression that is detected by surrounding $\mathrm{CD} 8^{+} \mathrm{T}$ cells that release interferon- $\gamma$ and granzyme $\mathrm{B}$, mediators capable of inhibiting lytic gene expression. Disruption of $\mathrm{CD}^{+} \mathrm{T}$ cell inhibition of viral lytic gene expression could lead to reactivation from initial ganglionic neuron steady-state low-level gene expression. Some of the specific stimuli associated with reactivation include menstruation in women and psychological and physiological stress. Treatment with medroxyprogesterone acetate, a synthetic analogue of the female sex hormone progesterone, released during ovulation, has been shown to be capable of reducing $\mathrm{CD} 8^{+} \mathrm{T}$ cell levels in the trigeminal ganglia of latently infected mice (Himmelein expression; miR-H2 acts on ICP0 and miR-H6 acts on ICP4. By preventing translation of lytic genes required for reactivation, small noncoding RNAs derived from LAT promote the maintenance of latency. Granzyme B (GrzB) and interferon- $\gamma(\mathrm{IFN}-\gamma)$ released from $\mathrm{CD}^{+} \mathrm{T}$ lymphocytes also contributes to the maintenance of latency. GrzB cleaves the ICP4 protein and IFN- $\gamma$ inhibits expression of ICP0

et al. 2011). Psychological and physiological stress have also resulted in a reduction of $\mathrm{CD} 8^{+} \mathrm{T}$ cells in the trigeminal ganglia and reduced capacity to secrete interferon- $\gamma$ (Freeman et al. 2008). The stress response is mediated through release of the glucocorticoid cortisol, which has been shown to reduce interferon- $\gamma$ expression in T cells (Curtin et al. 2009).

The mechanism by which $\mathrm{CD} 8^{+} \mathrm{T}$ cells inhibit lytic gene expression is through the release of interferon- $\gamma$ and granzymes A and B. Release of granzyme B is a primary method through which $\mathrm{CD}^{+} \mathrm{T}$ cells induce apoptosis in virus-infected cells. However, neurons harboring latent HSV-1 are protected from granzyme B-induced apoptosis (Knickelbein et al. 2009). The exact mechanisms of this protection have not been thoroughly explored, but it appears that LAT is critical for inhibiting apoptosis in infected neurons (Jiang et al. 2011). The inhibition of apoptosis in latently infected neurons reflects the other side of the careful balance that allows the latent infection to be maintained. Disruption of this balance is another mechanism through which external stimuli can potentially induce reactivation. If neurons that harbor the latent viral genome are induced to undergo apoptosis, the virus reactivates and 
releases infectious virions (Fig. 4). The pathway through which apoptotic signals initiate reactivation is unknown. This is potentially a mechanism by which physical damage to neurons induces reactivation. Additionally, apoptotic signals can be a mechanism by which ultraviolet (UV) light could induce reactivation from latency. The axons of innervating neurons extend into the periphery and are in proximity to the surface of the skin and could be susceptible to UV light exposure. UV light can induce apoptosis in cells through either direct damage of DNA or by production of reactive oxygen species (ROS) (Kulms et al. 2002). Mitochondria in neurons are uniformly distributed throughout the neuron, including the axon (Hollenbeck 1996). UV light exposure can induce production of ROS in mitochondria residing near the axonal terminal, which could lead to apoptotic signaling. ROS is associated with reducing expression and levels of Bcl-2 and inhibiting mammalian target of rapamycin (Alexander et al. 2010), responses that have been shown to induce reactivation (Kobayashi et al. 2012).

Recently, Du et al. (2012) demonstrated an interesting feature of reactivation when neurons are treated with chemical agents that reduce levels of Bcl-2 and Bcl-xl. The expression of the viral genome did not proceed according to the ordinary temporal pattern observed in primary infection. In contrast to sequential expression of the $\alpha, \beta$, and $\gamma$ genes, all gene classes were expressed at the same time upon induction of apoptosis. This is a mechanism by which the virus can rapidly produce new virions in response to signals that indicate that the cell in which it is residing is no longer viable. Rapid virus assembly and escape allows the virus to infect peripheral epithelial and neuronal cells to remain in the host.

\section{Tissue resident memory $\mathrm{T}$ cells and HSV-1}

It is possible that the $\mathrm{CD} 8^{+} \mathrm{T}$ cells surrounding latently infected ganglia belong to a novel subset of memory $\mathrm{T}$ cells recently described called tissue resident memory $T$ cells $\left(T_{R M}\right)$. Following antigenic exposure, two distinct populations of memory $\mathrm{T}$ cells are normally found. Central memory $\mathrm{T}\left(\mathrm{T}_{\mathrm{CM}}\right)$ cells are retained in secondary lymphoid organs and have the capacity to rapidly proliferate upon reexposure to antigen. These are characterized by specific cell surface markers $\mathrm{CD} 44^{+} \mathrm{CCR} 7^{+}$ $\mathrm{CD}_{2} \mathrm{~L}^{+}$. In contrast to central memory $\mathrm{T}$ cells, effector memory $\mathrm{T}\left(\mathrm{T}_{\mathrm{EM}}\right)$ cells are $\mathrm{CD} 44^{+} \mathrm{CCR} 7^{-} \mathrm{CD} 2 \mathrm{~L}^{-}$(Harty and Badovinac 2008). The $\mathrm{T}_{\mathrm{EM}}$ cells circulate through the blood and various tissues, sampling the environment for their specific antigen. These cells are already differentiated and are capable of
Fig. 4 Pathways of stimuli induced reactivation. Low-level temporal expression of lytic genes can lead to production of the transcription factor complex and efficient temporal expression of lytic genes. This low-level expression is normally inhibited by factors released from surrounding $\mathrm{CD} 8^{+} \mathrm{T}$ cells. Interferon- $\gamma($ IFN- $\gamma)$ inhibits ICP0 expression and granzyme B (GrzB) cleaves the ICP4 protein required for efficient expression of lytic genes. Stimuli such as hormone imbalance and stress inhibit $\mathrm{CD}^{+} \mathrm{T}$ cell activity, which allows low-level lytic gene expression to continue. Lytic gene expression leads to assembly of viral components, release, and reactivation (right). Alternatively, stimuli such as UV light and physical trauma initiate gene transcription through apoptotic signals. Apoptotic signaling leads to uncoordinated expression of lytic genes and production of new infectious viruses and reactivation (left)

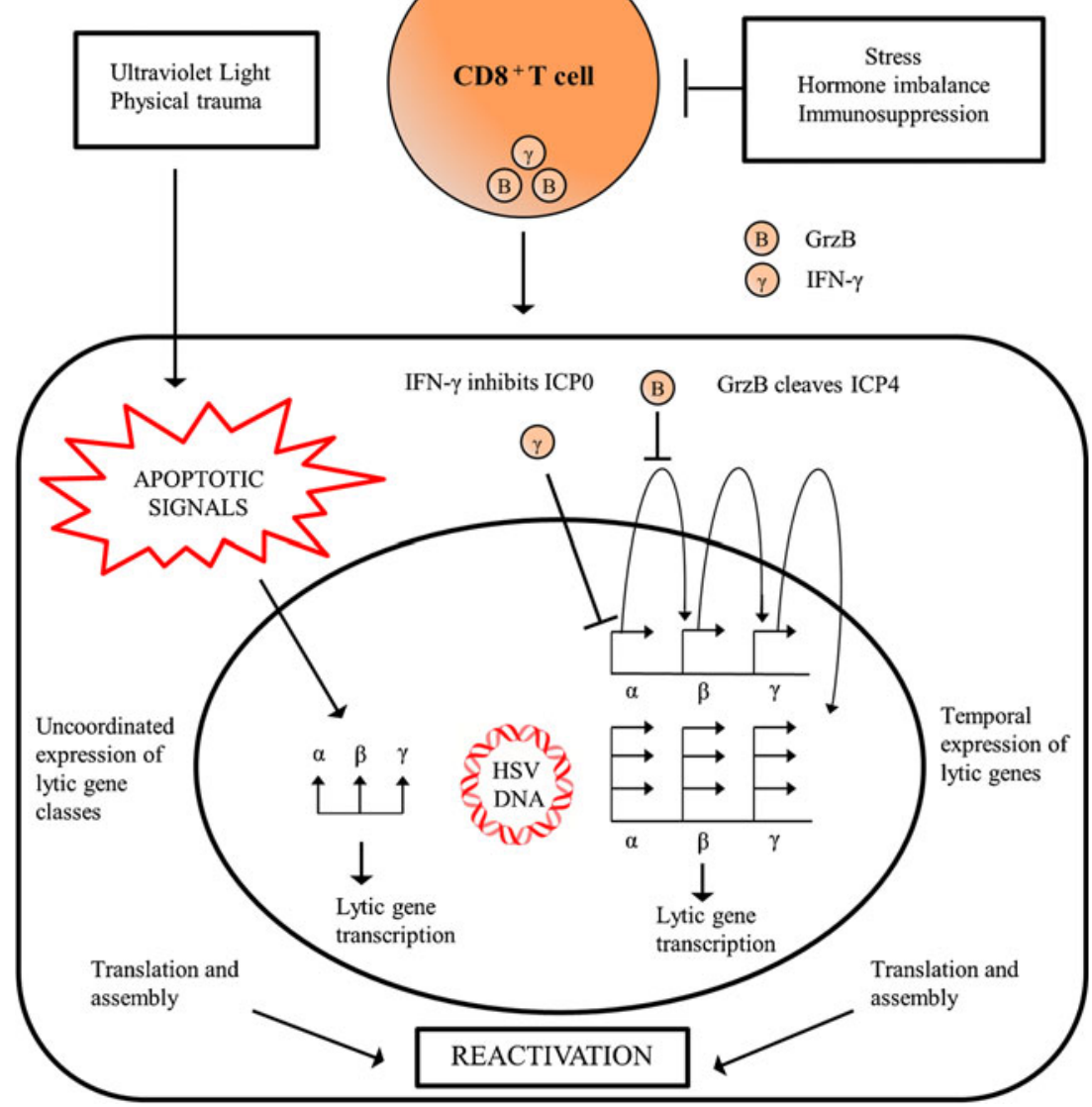


immediate effector functions and can begin clearing infections without the need to proliferate and differentiate. Memory T cell responses provide fast responses to reinfection, as opposed to how they respond to novel antigens, but they rely on the specific antigen to be delivered to secondary lymphoid organs (for $\mathrm{T}_{\mathrm{CM}}$ cells) or for the antigen-specific $\mathrm{T}_{\mathrm{EM}}$ cell to be present at the site of reinfection at the same time. A population of memory $\mathrm{T}$ cells that reside long term at the site of initial infection would be capable of immediate response to antigenic exposure in the site where exposure is likely to occur.

Recent evidence supports the notion of a distinct population of memory $\mathrm{T}$ cells that are retained in the tissue of initial exposure. $\mathrm{T}_{\mathrm{RM}}$ cells have been found in numerous tissues in the body, including brain parenchyma (Hawke et al. 1998), skin (Gebhardt et al. 2009), genital mucosa (Tang and Rosenthal 2010), gut ileum (Masopust et al. 2010), salivary glands (Casey et al. 2012), and the dorsal root ganglia (Gebhardt et al. 2009). Although surface marker characterization has not been done with $\mathrm{T}_{\mathrm{RM}}$ from all these locations, some distinctive phenotypic markers have been identified. $\mathrm{T}_{\mathrm{RM}}$ cells are $\mathrm{CD} 44^{+} \mathrm{CCR} 7^{-} \mathrm{CD} 6 \mathrm{~L}^{-} \mathrm{CD} 9^{+} \mathrm{CD} 103^{+}$ (Wakim et al. 2012). CD103 has not been found in all tissue sources of $T_{R M}$ cells, but it does appear in the majority of $T_{R M}$ cells isolated. CD103 is the $\alpha$ chain of the $\alpha 4 \beta 7$ integrin receptor for E-cadherin normally expressed in epithelial cells (Cepek et al. 1994). An important characteristic of $\mathrm{T}_{\mathrm{RM}}$ cells is that they do not migrate through the periphery or enter into the secondary lymphoid organs; expression of CD103 likely allows $T_{R M}$ cells to be retained in tissue compartments. $T_{R M}$ cells have been shown to be capable of persisting for extended periods in these peripheral tissue compartments without replenishment from the circulating pool of $\mathrm{CD}^{+} \mathrm{T}$ cells owing to low homeostatic turnover (Gebhardt et al. 2009; Masopust et al. 2006). An interesting distinction of $T_{R M}$ cells is their apparent ability to survive without IL-15 signaling, even in the absence of antigenic exposure (Wakim et al. 2010). The combination of CD103 expression and long-term residence in tissues where antigen was initially encountered distinguishes $T_{R M}$ cells from the established memory $T$ cells.

With the recent characterization of $T_{R M}$ cells, it is important to analyze what other $\mathrm{T}$ cell populations might belong to this novel subclass. In latent HSV-1 infection, $\mathrm{CD}^{+} \mathrm{T}$ cells surrounding infected neurons in the trigeminal ganglia persist for the lifetime of the organism and are vital in maintaining the virus in a latent state (Hoshino et al. 2007; Liu et al. 2000). This is accomplished through expression of effector molecules, and therefore HSV-1-specific $\mathrm{CD}^{+}{ }^{+} \mathrm{T}$ cells have an activated phenotype akin to effector memory cells. Activated $\mathrm{CD}^{+} \mathrm{T}$ cells have the markers CD69, CD44, CD25, and CD49d expressed on their surface. They downregulate homing receptors CD62L and CCR7 (Barrat et al. 1995; Lynch et al. 1989) and the markers of naive $\mathrm{CD} 8^{+} \mathrm{T}$ cells $\mathrm{CD} 27$ and CD28 (Verjans et al. 2007). Additionally, the $\mathrm{CD} 8^{+} \mathrm{T}$ cells in the trigeminal ganglia express granzymes $\mathrm{A}$ and $\mathrm{B}$ and interferon- $\gamma$. Like $\mathrm{T}_{\mathrm{RM}}$ cells, IL-15 is not required to maintain the population within the trigeminal ganglia (Sheridan et al. 2006). The $\alpha 4 \beta 7$ integrin CD103 is a marker used to consistently identify $\mathrm{T}_{\mathrm{RM}}$ cells, but no experiments have addressed whether CD103 is present on the surface of trigeminal ganglia resident $\mathrm{CD} 8^{+} \mathrm{T}$ cells.

Additionally, the migration pattern of $\mathrm{CD} 8^{+} \mathrm{T}$ cells differs extensively from patterns observed with $\mathrm{T}_{\mathrm{EM}}$ cells. Principally, $\mathrm{CD} 8^{+} \mathrm{T}$ cells never leave the trigeminal ganglia once they have infiltrated and surrounded latently infected neurons (Khanna et al. 2003). Whereas $\mathrm{T}_{\mathrm{EM}}$ cells migrate through various tissues and can participate in peripheral immune responses to antigen reexposure, $\mathrm{CD} 8^{+} \mathrm{T}$ cells reside in the trigeminal ganglia for the lifetime of the host. Himmelein et al. (2011) provided evidence of the peculiar homing pattern of the HSV-1-specific CD8 $8^{+} \mathrm{T}$ cells retained in the trigeminal. Following treatment with corticosteroids and challenged with restraining stress, stimuli proven to reduce $\mathrm{CD} 8^{+} \mathrm{T}$ cell levels in the trigeminal ganglia (Elftman et al. 2010; Freeman et al. 2008), the population of $\mathrm{CD} 8^{+} \mathrm{T}$ cells in the trigeminal ganglia is quickly reestablished (within 4 days). Importantly, the trigeminal population is not supplemented with $\mathrm{CD}^{+} \mathrm{T}$ cells from the circulation, nor is it due to proliferation of residual $\mathrm{CD} 8^{+} \mathrm{T}$ cells in the trigeminal ganglia immediately after the treatment. These results imply that the $\mathrm{CD} 8^{+} \mathrm{T}$ cells that left the trigeminal ganglia are capable of homing back to their original location. $\mathrm{CD} 8^{+} \mathrm{T}$ cells in the periphery are incapable of infiltrating the trigeminal ganglia, which prevents supplementation or replacement of the population from the circulating pool of $\mathrm{CD}^{+} \mathrm{T}$ cells. The same population is not maintained based on the proliferation of resident $\mathrm{CD} 8^{+} \mathrm{T}$ cells; instead, these cells have very low homeostatic turnover.

Currently available information on trigeminal resident $\mathrm{CD}^{+} \mathrm{T}$ cell surface markers indicates they could fall into either the $T_{E M}$ class or the recently discovered $T_{R M}$ class (Table 1). The migration dynamics are the primary evidence that the trigeminal ganglia resident $\mathrm{CD} 8^{+} \mathrm{T}$ cells could be $\mathrm{T}_{\mathrm{RM}}$ cells instead of $\mathrm{T}_{\mathrm{EM}}$ cells. These $\mathrm{T}$ cells are retained in the same tissue compartment for the lifetime of the host and home back to the same location if dislodged. These cells survive in the tissue compartment without being replenished from circulating pools of $\mathrm{CD} 8^{+} \mathrm{T}$ cells, have low homeostatic turnover, and do not require IL-15 for survival. Further characterization of the cell surface phenotype of this cell population is needed to definitively classify them as being either $\mathrm{T}_{\mathrm{RM}}$ or $\mathrm{T}_{\mathrm{EM}}$ cells.

\section{$T_{R M}$ cells and immunity to viruses}

Gebhardt et al. (2009) studied the response of $T_{R M}$ cells to reinfection extensively in the context of HSV-1 skin infection. Following flank infection with HSV-1, they found an accumulation of adoptively transferred $\mathrm{HSV}-1$-specific $\mathrm{CD} 8^{+} \mathrm{T}$ 
Table 1 Phenotypic markers of memory $\mathrm{CD}^{+} \mathrm{T}$ cells

\section{Memory T cell subtypes}

$\mathrm{T}_{\mathrm{CM}} \mathrm{T}_{\mathrm{EM}} \quad \mathrm{T}_{\mathrm{RM}}$ Trigeminal ganglia resident $\mathrm{CD} 8^{+}$

\begin{tabular}{lllll}
\hline $\mathrm{CD} 44$ & + & + & + & + \\
$\mathrm{CD} 69$ & - & - & + & + \\
$\mathrm{CD} 103$ & - & - & + & \\
Tissue retention & + & - & + & + \\
$\begin{array}{l}\text { Effector } \\
\quad \text { function }\end{array}$ & - & + & + & + \\
\hline
\end{tabular}

$T_{C M}$ central memory T cells, $T_{E M}$ effector memory $\mathrm{T}$ cells, $T_{R M}$ tissue resident memory $\mathrm{T}$ cells

cells ipsilateral to the infection site but not on the control infection site. These cells were located in the epithelial layer of skin; had a surface marker phenotype $\mathrm{CD} 69^{+} \mathrm{VLAl}^{+}$ $\mathrm{CD}_{103}{ }^{+} \mathrm{CD} 6 \mathrm{~L}^{-} \mathrm{CD} 122^{-}$; did not migrate; and had a slow homeostatic turnover. Importantly, when challenged with virus following a previous exposure and clearance of virus, the skin flanks with residing $\mathrm{T}_{\mathrm{RM}}$ cells had much better protection than the control flank. This enhanced protection was shown to be T cell-dependent, with contributions from both $\mathrm{CD}^{+} \mathrm{T}$ and $\mathrm{CD}^{+}$T cells. Eliminating $\mathrm{CD} 4^{+} \mathrm{T}$ cells had a significant effect on clearance, but when provided with excess $\mathrm{CD} 8^{+} \mathrm{T}$ cells, they were capable of clearance without the help of $\mathrm{CD}^{+} \mathrm{T}$ cells.

It is important to note that the results described above involved reexposure to exogenous virus and cannot be directly related to skin $T_{R M}$ cells responding to reactivation of virus. Mouse models of latent HSV-1 infection have very rare episodes of spontaneous reactivation (Gebhardt and Halford 2005), and thus chemical agents or stressful stimuli, which often decrease trigeminal ganglia resident $\mathrm{CD} 8^{+} \mathrm{T}$ cells, are required for reactivation. It is unknown what effect these agents might have on $T_{R M}$ cells in the skin and whether they have any effect on virus clearance. Humans do experience spontaneous reactivation or reactivation as a result of certain exogenous agents. Reactivation of latent virus can result in asymptomatic shedding of virus or may cause formation of recrudescent lesions in the same peripheral location where the primary infection occurred. Recurrent disease provides circumstantial evidence that if $T_{R M}$ cells exist in humans, they either do not prevent reinfection where they reside or the agent responsible for reactivation also has an effect on peripheral $\mathrm{T}_{\mathrm{RM}}$ cells.

Rates of reactivation are inversely correlated with the number of $\mathrm{CD} 8^{+} \mathrm{T}$ cells infiltrating the trigeminal ganglia and have been directly correlated with the number of latently infected neurons (Hoshino et al. 2007). Initial hopes that HSV-1specific $\mathrm{CD}^{+} \mathrm{T}$ cells could be expanded in vitro and then adopted into the host as a method to reduce reactivation rates have failed because adopted $\mathrm{CD} 8^{+} \mathrm{T}$ cells cannot access the trigeminal compartment where latently infected neurons reside (Himmelein et al. 2011). It is possible that critical comparisons of circulating and resident ganglionic $\mathrm{CD} 8^{+} \mathrm{T}$ cells will reveal new information that will make it possible to adoptively transfer $\mathrm{T}$ cells into the trigeminal compartment in order to reduce reactivation and recurrent disease. This method would not be capable of eliminating the latent infection, but a robust immune presence is capable of limiting virus reactivation from latency.

Despite decades of research on HSV-1, there is still no effective vaccine that can prevent virus infection or control reactivation (Dervillez et al. 2012). Following primary infection in the periphery, released virions encounter and infect innervating sensory neurons. The virus attaches to the axonal terminal and releases the capsid and tegument proteins, which migrate retrograde toward the neuronal soma where the DNA is uncoated, injected into the nucleus, and latency is established very early during the course of the primary infection. During reactivation, capsids are assembled in the nucleus and then are transported across the nuclear membrane as enveloped particles, and then they travel anterograde toward the axonal terminal region with infectious virions released into the periphery (Smith 2012). This implies that, during the migration of virus from the latent reservoir to target cells, few locations exist where neutralizing antibodies can act upon the virus before it is exposed to target cells. There is a robust immune response leading to expanded $\mathrm{CD}^{+} \mathrm{T}$ cell populations surrounding infected cells in the trigeminal, but these cells are incapable of eliminating the virus, only of limiting viral reactivation. This means that the primary location where a vaccine must be effective is the site of primary infection.

Mackay et al. (2012) revealed that expanded HSV-specific $\mathrm{T}_{\mathrm{RM}}$ cells in the periphery are capable of limiting disease from reexposure to HSV-1. These experiments suggest an exciting new direction for creating a vaccine to prevent new infections or limit the severity of recurrent disease. Shin and Iwasaki (2012) adapted this idea and hypothesized that a "prime and pull" technique can generate large numbers of virus-specific $\mathrm{CD}^{+} \mathrm{T}$ cells in the periphery, where they can stop or limit damage from infection. The "prime" is composed of a subcutaneous injection of thymidine kinase (TK ) HSV-2 virus, capable of activating and proliferating adoptively transferred $\mathrm{CD} 8^{+} \mathrm{T}$ cells. The "pull" is accomplished by topical treatment of CXCL9 and CXCL10 chemokines applied to the vaginal cavity. The chemokine treatment attracted many more $\mathrm{CD} 8^{+} \mathrm{T}$ cells to the vagina compared with immunization without chemokine treatment. Treatment provided after the central pool of CD $8^{+} \mathrm{T}$ cells had been activated successfully recruited and maintained $\mathrm{T}$ cells in the genital tract for up to 12 weeks after treatment. When challenged with a lethal dose of wildtype HSV-2, mice receiving the immunization and chemokine treatment suffered less weight loss, did not develop clinical 
symptoms, and had a $100 \%$ survival rate. Importantly, viral titers found in the DRG following WT infection were significantly decreased compared with immunization alone. Because reactivation rates are directly correlated with latent viral load, a therapeutic intervention that lowers the initial viral infection of the DRG would be beneficial. This novel vaccine treatment appears to have successfully lowered the viral burden on the DRG, decreased the number of latent viral genomes, and would like significantly decrease reactivation and recurrent disease in humans.

\section{Conclusions}

HSV-1 represents a persistent human pathogen that resides in infected hosts for their lifetime. Clearance of the primary infection follows establishment of the latent infection within the ganglionic clusters of innervating sensory neurons. Reactivation of the virus is controlled at least in part by $\mathrm{CD}^{+} \mathrm{T}$ cells that surround latently infected neurons. An important feature of these cells is their long-term residence in the neuronal tissue compartment. HSV-1-specific $\mathrm{CD} 8^{+} \mathrm{T}$ cells can remain in the trigeminal ganglia for the lifetime of the host, do not rely on replenishment from circulating $\mathrm{CD} 8^{+} \mathrm{T}$ cells, and have the capability to home back to the trigeminal ganglia if displaced. These behaviors distinguish the resident ganglionic $\mathrm{CD}^{+} \mathrm{T}$ cells from the traditional $\mathrm{CD}^{+} \mathrm{T}$ cell memory subsets.

Recently, a new class of $\mathrm{CD} 8^{+}$memory T cells that reside in peripheral tissue compartments has been characterized. The phenotypic characteristics of the $T_{R M}$ cell are similar to those of the trigeminal ganglia resident $\mathrm{CD} 8^{+} \mathrm{T}$ cells that arise in response to HSV-1 infections. Both cell types exist in peripheral tissue compartments for long periods, have low homeostatic turnover, are not replenished from the circulating $\mathrm{CD} 8^{+}$ $\mathrm{T}$ cell pool, and express the effector molecules interferon- $\gamma$ and granzyme $\mathrm{B}$. The CD103 integrin receptor is a surface marker used to identify $\mathrm{T}_{\mathrm{RM}}$ cells in peripheral tissues, but its expression has not been evaluated in trigeminal ganglia resident $\mathrm{CD} 8^{+} \mathrm{T}$ cells. Identification of $\mathrm{HSV}-1$-specific $\mathrm{CD} 8^{+} \mathrm{T}$ cells as $\mathrm{T}_{\mathrm{RM}}$ cells can lead to exploration of new approaches toward reducing disease in humans. Discovery of the factors associated with homing of the trigeminal resident $\mathrm{CD} 8^{+} \mathrm{T}$ cells back to the peripheral nervous system compartment may lead to new ways of bolstering the $\mathrm{CD} 8^{+} \mathrm{T}$ cell levels in the trigeminal ganglia to lower reactivation rates. New vaccine approaches designed to attract and retain $T_{R M}$ cells in peripheral tissue locations in response to immunization could lower viral burden on peripheral nervous system following exposure to virus.

Acknowledgments The authors would like to acknowledge Drs. Christina Kollias and Michael Nonnemacher for help in creating the figures. We also thank Diana Winters, Drexel University College of
Medicine Academic Publishing Services, for providing critical reading and offering suggestions for the manuscript. This work was supported in part by US PHS NIH/NIAID R01 grant AI49428 (Principal Investigator, Stephen R. Jennings) and by faculty development funds provided by the Department of Microbiology and Immunology and the Institute for Molecular Medicine and Infectious Disease, Drexel University College of Medicine. This work was also supported in part by funds from the Public Health Service, National Institutes of Health, through grants from the National Institute of Neurological Disorders and Stroke [NS32092, Principal Investigator, Brian Wigdahl] and the National Institute of Drug Abuse [DA19807, Principle Investigator, Brian Wigdahl].

Conflict of interest The authors declare that they have no conflict of interest.

Open Access This article is distributed under the terms of the Creative Commons Attribution License which permits any use, distribution, and reproduction in any medium, provided the original author(s) and the source are credited.

\section{References}

Alexander A, Cai SL, Kim J, Nanez A, Sahin M, MacLean KH, Inoki K, Guan KL, Shen J, Person MD, Kusewitt D, Mills GB, Kastan MB, Walker CL (2010) ATM signals to TSC2 in the cytoplasm to regulate mTORC1 in response to ROS. Proc Natl Acad Sci USA 107:4153-4158. doi:10.1073/pnas.0913860107

Ankel H, Westra DF, Welling-wester S, Lebon P (1998) Induction of interferon- $\alpha$ by glycoprotein $D$ of herpes simplex virus: a possible role of chemokine receptors. Virology 251:317-326. doi:10.1006/ viro.1998.9432

Ashkar AA, Rosenthal KL (2003) Interleukin-15 and natural killer and NKT cells play a critical role in innate protection against genital herpes simplex virus type 2 infection. J Virol 77:10168-10171. doi:10.1128/JVI.77.18.10168-10171.2003

Aubert M, Krantz EM, Jerome KR (2006) Herpes simplex virus genes Us3, Us5, and Us12 differentially regulate cytotoxic T lymphocyteinduced cytotoxicity. Viral Immunol 19:391-408. doi:10.1089/vim. 2006.19.391

Barrat F, Haegel H, Louise A, Vincent-Naulleau S, Boulouis HJ, Neway T, Ceredig R, Pilet C (1995) Quantitative and qualitative changes in CD44 and MEL-14 expression by T cells in C57BL/6 mice during aging. Res Immunol 146:23-34. doi:10.1016/0923-2494(96)80237-9

Belich MP, Glynne RJ, Senger G, Sheer D, Trowsdale J (1994) Proteasome components with reciprocal expression to that of the MHC-encoded LMP proteins. Curr Biol 4:769-776. doi:10.1016/ S0960-9822(00)00174-3

Benedict CA, Norris PS, Ware CF (2002) To kill or be killed: viral evasion of apoptosis. Nat Immunol 3:1013-1018. doi:10.1038/ nil102-1013

Bertke AS, Swanson SM, Chen J, Imai Y, Kinchington PR, Margolis TP (2011) A5-positive primary sensory neurons are nonpermissive for productive infection with herpes simplex virus 1 in vitro. J Virol 85:6669-6677. doi:10.1128/JVI.00204-11

Bertke AS, Apakupakul K, Ma A, Imai Y, Gussow AM, Wang K, Cohen JI, Bloom DC, Margolis TP (2012) LAT region factors mediating differential neuronal tropism of HSV-1 and HSV-2 do not act in trans. PLoS One 7:e53281. doi:10.1371/journal.pone.0053281

Bloom DC (2004) HSV LAT and neuronal survival. Int Rev Immunol 23:187-198. doi:10.1080/08830180490265592

Bloom DC, Giordani NV, Kwiatkowski DL (2010) Epigenetic regulation of latent HSV-1 gene expression. Biochim Biophys Acta 1799:246256. doi:10.1016/j.bbagrm.2009.12.001 
Bosnjak L, Miranda-Saksena M, Koelle DM, Boadle RA, Jones CA, Cunningham AL (2012) Herpes simplex virus infection of human dendritic cells induces apoptosis and allows cross-presentation via uninfected dendritic cells. J Immunol 174:2220-2227

Boss IW, Renne R (2010) Viral miRNAs: tools for immune evasion. Curr Opin Microbiol 13:540-545. doi:10.1016/j.mib.2010.05.017

Brady RC, Bernstein DI (2004) Treatment of herpes simplex virus infections. Antiviral Res 61:73-81. doi:10.1016/j.antiviral.2003.09.006

Branco FJ, Fraser NW (2005) Herpes simplex virus type 1 latencyassociated transcript expression protects trigeminal ganglion neurons from apoptosis. J Virol 79:9019-9025. doi:10.1128/JVI.79.14. 9019

Burgos JS, Serrano-Saiz E, Sastre I, Valdivieso F (2006) ICP47 mediates viral neuroinvasiveness by induction of TAP protein following intravenous inoculation of herpes simplex virus type 1 in mice. J Neurovirol 12:420-427. doi:10.1080/13550280601009546

Camarena V, Kobayashi M, Kim JY, Roehm P, Perez R, Gardner J, Wilson AC, Mohr I, Chao MV (2010) Nature and duration of growth factor signaling through receptor tyrosine kinases regulates HSV-1 latency in neurons. Cell Host Microbe 8:320-330. doi:10. 1016/j.chom.2010.09.007.Nature

Campadelli-Fiume G, Amasio M, Avitabile E, Cerretani A, Forghieri C, Gianni T, Menotti L (2007) The multipartite system that mediates entry of herpes simplex virus into the cell. Rev Med Virol 17:313326. doi:10.1002/rmv.546

Carfi A, Willis SH, Whitbeck JC, Krummenacher C, Cohen GH, Eisenberg RJ, Wiley DC (2001) Herpes simplex virus glycoprotein D bound to the human receptor HveA. Molecular Cell 8:169-179. doi:10.1016/S1097-2765(01)00298-2

Carpenter D, Hsiang C, Brown DJ, Jin L, Osorio N, BenMohamed L, Jones C, Wechsler SL (2007) Stable cell lines expressing high levels of the herpes simplex virus type 1 LAT are refractory to caspase 3 activation and DNA laddering following cold shock induced apoptosis. Virology 369:12-18. doi:10.1016/j.virol.2007.07.023

Carr DJJ, Austin BA, Halford WP, Stuart PM (2009) Delivery of Interferon-gamma by an adenovirus vector blocks herpes simplex virus type 1 reactivation in vitro and in vivo independent of RNase $\mathrm{L}$ and double-stranded RNA-dependent protein kinase pathways. J Neuroimmunol 206:39-43. doi:10.1016/j.jneuroim.2008.10.008

Casey KA, Fraser KA, Schenkel JM, Moran A, Abt MC, Beura LK, Lucas PJ, Artis D, Wherry EJ, Hogquist K, Vezys V, Masopust D (2012) Antigen-independent differentiation and maintenance of effector-like resident memory $\mathrm{T}$ cells in tissues. $\mathrm{J}$ Immunol 188:4866-4875. doi:10.4049/jimmunol.1200402

Cepek KL,Shaw SK, Parker CM, Russell GJ, Morrow JS, Rimm DL, Brenner MB (1994) Adhesion between epithelial cells and T lymphocytes mediated by E-cadherin and the alpha E beta 7 integrin. Nature 372:190-193. doi:10.1038/372190a0

Cheng H, Tumpey TM, Staats HF, van Rooijen N, Oakes JE, Lausch RN (2000) Role of macrophages in restricting herpes simplex virus type 1 growth after ocular infection. Invest Ophthalmol Vis Sci 41:1402-1409

Chentoufi AA, Kritzer E, Tran MV, Dasgupta G, Lim CH, Yu DC, Afifi RE, Jiang X, Carpenter D, Osorio N, Hsiang C, Nesburn AB, Wechsler SL, BenMohamed L (2011) The herpes simplex virus 1 latency-associated transcript promotes functional exhaustion of virus-specific $\mathrm{CD} 8+\mathrm{T}$ cells in latently infected trigeminal ganglia: a novel immune evasion mechanism. J Virol 85:9127-9138. doi:10. 1128/JVI.00587-11

Chentoufi AA, Kritzer E, Yu DM, Nesburn AB, Benmohamed L (2012) Towards a rational design of an asymptomatic clinical herpes vaccine: the old, the new, and the unknown. Clin Dev Immunol 2012:187585. doi:10.1155/2012/187585

Cliffe AR, Garber DA, Knipe DM (2009) Transcription of the herpes simplex virus latency-associated transcript promotes the formation of facultative heterochromatin on lytic promoters. J Virol 83:81828190. doi:10.1128/JVI.00712-09
Conrady CD, Zheng M, Fitzgerald KA, Liu C, Carr DJ (2012) Resistance to HSV-1 infection in the epithelium resides with the novel innate sensor, IFI-16. Mucosal Immunol 5:173-183. doi:10.1038/mi.2011.63

Curtin NM, Boyle NT, Mills KHG, Connor TJ (2009) Psychological stress suppresses innate IFN-gamma production via glucocorticoid receptor activation: reversal by the anxiolytic chlordiazepoxide. Brain Behav Immun 23:535-547. doi:10.1016/j.bbi.2009.02.003

Decman V, Kinchington PR, Harvey SAK, Hendricks RL (2005) Gamma interferon can block herpes simplex virus type 1 reactivation from latency, even in the presence of late gene expression. J Virol 79:10339-10347. doi:10.1128/JVI.79.16.10339

Dervillez X, Gottimukkala C, Kabbara KW, Nguyen C, Badakhshan T, Kim SM, Nesburn AB, Wechsler SL, Benmohamed L (2012) Future of an "asymptomatic" T-cell epitope-based therapeutic herpes simplex vaccine. Futur Virol 7:371-378. doi:10.2217/fvl.12.22.Future

Deshpande SP, Kumaraguru U, Rouse BT (2000) Dual role of B cells in mediating innate and acquired immunity to herpes simplex virus infections. Cell Immunol 202:79-87. doi:10.1006/cimm.2000.1666

Drolet BS, Perng GC, Cohen J, Slanina SM, Yukht A, Nesburn AB, Wechsler SL (1998a) The region of the herpes simplex virus type 1 LAT gene involved in spontaneous reactivation does not encode a functional protein. Virology 242:221-232. doi:10.1006/viro.1997. 9020

Drolet BS, Perng GC, Cohen J, Slanina SM, Yukht A, Nesburn AB, Wechsler SL (1998b) The region of the herpes simplex virus type 1 LAT gene involved in spontaneous reactivation does not encode a functional protein. Virology 242:221-232. doi:10.1006/viro.1997. 9020

Du T, Zhou G, Roizman B (2012) Induction of apoptosis accelerates reactivation of latent HSV-1 in ganglionic organ cultures and replication in cell cultures. Proc Natl Acad Sci USA 109:14616-14621. doi:10.1073/pnas. 1212661109

Elftman MD, Hunzeker JT, Mellinger JC, Bonneau RH, Norbury CC, Truckenmiller ME (2010) Stress-induced glucocorticoids at the earliest stages of herpes simplex virus-1 infection suppress subsequent antiviral immunity, implicating impaired dendritic cell function. J Immunol 184:1867-1875. doi:10.4049/ jimmunol.0902469

Elmore S (2007) Apoptosis: a review of programmed cell death. Toxicol Pathol 35:495-516. doi:10.1080/01926230701320337

Esaki S, Goshima F, Katsumi S, Watanabe D, Ozaki N, Murakami S, Nishiyama Y (2010) Apoptosis induction after herpes simplex virus infection differs according to cell type in vivo. Arch Virol 155:1235-1245. doi:10.1007/s00705-010-0712-2

Fan Z, Beresford PJ, Oh DY, Zhang D, Lieberman J (2003) Tumor suppressor NM23-H1 is a granzyme A-activated DNase during CTLmediated apoptosis, and the nucleosome assembly protein SET is its inhibitor. Cell 112:659-672. doi:10.1016/S0092-8674(03)00150-8

Feldman LT, Ellison AR, Voytek CC, Yang L, Krause P, Margolis TP (2002) Spontaneous molecular reactivation of herpes simplex virus type 1 latency in mice. Proc Natl Acad Sci USA 99:978-983. doi:10.1073/pnas.022301899

Flores O, Nakayama S, Whisnant AW, Javanbakht H, Cullen BR, Bloom DC (2013) Mutational inactivation of herpes simplex virus 1 microRNAs identifies viral mRNA targets and reveals phenotypic effects in culture. J Virol 87:6589-6603. doi:10. 1128/JVI.00504-13

Freeman ML, Sheridan BS, Bonneau RH, Hendricks RL (2008) Psychological stress compromises CD8+ T cell control of latent herpes simplex virus type 1 infections. J Immunol 179:322-328

Froelich CJ, Orth K, Turbov J, Seth P, Gottlieb R, Babior B, Shah GM, Bleackley RC, Dixit VM, Hanna W (1996) New paradigm for lymphocyte granule-mediated cytotoxicity. Target cells bind and internalize granzyme $\mathrm{B}$, but an endosomolytic agent is necessary for cytosolic delivery and subsequent apoptosis. J Biol Chem 271:29073-29079. doi:10.1074/jbc.271.46.29073 
Gebhardt BM, Halford WP (2005) Evidence that spontaneous reactivation of herpes virus does not occur in mice. Virol J 2:67. doi:10.1186/1743-422X-2-67

Gebhardt T, Wakim LM, Eidsmo L, Reading PC, Heath WR, Carbone FR (2009) Memory T cells in nonlymphoid tissue that provide enhanced local immunity during infection with herpes simplex virus. Nat Immuno 10:524-530. doi:10.1038/ni.1718

Gerster T (1988) A herpesvirus trans-activating protein interacts with transcription factor OTF-1 and other cellular proteins. Proc Natl Acad Sci 85:6347-6351. doi:10.1073/pnas.85.17.6347

Gottwein E, Cullen BR (2008) Viral and cellular microRNAs as determinants of viral pathogenesis and immunity. Cell Host Microbe 3:375-387. doi:10.1016/j.chom.2008.05.002

Groettrup M, Kraft R, Kostka S, Standera S, Stohwasser R, Kloetzel PM (1996) A third interferon-gamma-induced subunit exchange in the 20S proteasome. Eur J Immunol 26:863-869. doi:10.1002/eji.1830260421

Grubor-Bauk B, Arthur JL, Mayrhofer G (2008) Importance of NKT cells in resistance to herpes simplex virus, fate of virus-infected neurons, and level of latency in mice. J Virol 82:11073-11083. doi:10.1128/ JVI.00205-08

Guo Y, Audry M, Ciancanelli M, Alsina L, Azevedo J, Herman M, Anguiano E, Sancho-Shimizu V, Lorenzo L, Pauwels E, Philippe PB, Pérez de Diego R, Cardon A, Vogt G, Picard C, Andrianirina ZZ, Rozenberg F, Lebon P, Plancoulaine S, Tardieu M, Doireau V, Jouanguy E, Chaussabel D, Geissmann F, Abel L, Casanova JL, Zhang SY (2011) Herpes simplex virus encephalitis in a patient with complete TLR3 deficiency: TLR3 is otherwise redundant in protective immunity. J Exp Med 208:2083-2098. doi:10.1084/jem.20101568

Handunnetthi L, Ramagopalan SV, Ebers GC, Knight JC (2010) Regulation of major histocompatibility complex class II gene expression, genetic variation and disease. Genes Immunity 11:99-112. doi:10. 1038/gene. 2009.83

Harty JT, Badovinac VP (2008) Shaping and reshaping CD8+ T-cell memory. Nat Rev Immunol 8:107-119. doi:10.1038/nri2251

Harvat BL, Seth P, Jetten AM (1997) The role of p27Kip1 in gamma interferon-mediated growth arrest of mammary epithelial cells and related defects in mammary carcinoma cells. Oncogene 14:21112122. doi:10.1038/sj.onc. 1201055

Hawke S, Stevenson PG, Freeman S, Bangham CR (1998) Long-term persistence of activated cytotoxic $\mathrm{T}$ lymphocytes after viral infection of the central nervous system. J Exp Med 187:1575-1582. doi:10. 1084/jem.187.10.1575

Henderson G, Jaber T, Carpenter D, Wechsler SL, Jones C (2009) Identification of herpes simplex virus type 1 proteins encoded within the first $1.5 \mathrm{~kb}$ of the latency-associated transcript. J Neurovirol 15:439-448. doi:10.3109/13550280903296353

Hengartner MO (2000) The biochemistry of apoptosis. Nature 407:770 776. doi:10.1038/35037710

Herman M, Ciancanelli M, Ou YH, Lorenzo L, Klaudel-Dreszler M, Pauwels E, Sancho-Shimizu V, Pérez de Diego R, Abhyankar A, Israelsson E, Guo Y, Cardon A, Rozenberg F, Lebon P, Tardieu M, Heropolitanska-Pliszka E, Chaussabel D, White MA, Abel L, Zhang SY, Casanova JL (2012) Heterozygous TBK1 mutations impair TLR3 immunity and underlie herpes simplex encephalitis of childhood. J Exp Med 209:1567-1582. doi:10.1084/jem.20111316

Himmelein S, St Leger AJ, Knickelbein JE, Rowe A, Freeman ML, Hendricks RL (2011) Circulating herpes simplex type 1 (HSV-1)specific CD8+ T cells do not access HSV-1 latently infected trigeminal ganglia. Herpesviridae 2:5. doi:10.1186/2042-4280-2-5

Hollenbeck PJ (1996) The pattern and mechanism of mitochondrial transport in axons. Front Biosci 1:91-102

Hoshino Y, Pesnicak L, Cohen JI, Straus SE (2007) Rates of reactivation of latent herpes simplex virus from mouse trigeminal ganglia ex vivo correlate directly with viral load and inversely with number of infiltrating CD8+ T cells. J Virol 81:8157-8164. doi:10.1128/JVI. 00474-07
Irmler M, Hertig S, MacDonald HR, Sadoul R, Becherer JD, Proudfoot A, Solari R, Tschopp J (1995) Granzyme A is an interleukin 1betaconverting enzyme. J Exp Med 181:1917-1922. doi:10.1084/jem. 181.5.1917

Jerome KR, Fox R, Chen Z, Sears AE, Hy L, Corey L (1999) Herpes simplex virus inhibits apoptosis through the action of two genes, Us5 and Us3. J Virol 73:8950-8957

Jerome KR, Chen Z, Lang R, Torres MR, Hofmeister J, Smith S, Fox R, Froelich CJ, Corey L (2001) HSV and glycoprotein J inhibit caspase activation and apoptosis induced by granzyme B or Fas. J Immunol 167:3928-3935

Jiang X, Chentoufi AA, Hsiang C, Carpenter D, Osorio N, BenMohamed L, Fraser NW, Jones C, Wechsler SL (2011) The herpes simplex virus type 1 latency-associated transcript can protect neuron-derived C1300 and Neuro2A cells from granzyme B-induced apoptosis and CD8 T-cell killing. J Virol 85:2325-2332. doi:10.1128/JVI.0179110

Jin L, Carpenter D, Moerdyk-Schauwecker M, Vanarsdall AL, Osorio N, Hsiang C, Jones C, Wechsler SL (2010) Cellular FLIP can substitute for the herpes simplex virus type 1 latency-associated transcript gene to support a wild type virus reactivation phenotype in mice. J Neurovirol 14:389-400. doi:10.1080/13550280802216510

Jurak I, Griffiths A, Coen DM (2012) Mammalian alphaherpesviruses miRNAs. Biochim Biophys Acta 1809:641-653. doi:10.1016/j. bbagrm.2011.06.010

Kassim SH, Rajasagi NK, Zhao X, Chervenak R, Jennings SR (2006) In vivo ablation of CD11c-positive dendritic cells increases susceptibility to herpes simplex virus type 1 infection and diminishes NK and T-cell responses. J Virol 80:3985-3993. doi:10.1128/JVI.80.8. 3985-3993.2006

Kassim SH, Rajasagi NK, Ritz BW, Pruett SB, Gardner EM, Chervenak R, Jennings SR (2009) Dendritic cells are required for optimal activation of natural killer functions following primary infection with herpes simplex virus type 1. J Virol 83:3175-3186. doi:10. 1128/JVI.01907-08

Kather A, Raftery MJ, Devi-Rao G, Lippmann J, Giese T, Sandri-Goldin RM, Schönrich G (2010) Herpes simplex virus type 1 (HSV-1)induced apoptosis in human dendritic cells as a result of downregulation of cellular FLICE-inhibitory protein and reduced expression of HSV-1 antiapoptotic latency-associated transcript sequences. J Virol 84:1034-1046. doi:10.1128/JVI.01409-09

Kato H, Takeuchi O, Mikamo-Satoh E, Hirai R, Kawai T, Matsushita K, Hiiragi A, Dermody TS, Fujita T, Akira S (2008) Length-dependent recognition of double-stranded ribonucleic acids by acid-inducible gene-I and melanoma differentiation-associated gene 5. J Exp Med 205:1601-1610. doi:10.1084/jem.20080091

Kaye S, Choudhary A (2006) Herpes simplex keratitis. Prog Retin Eye Res 25:355-380. doi:10.1016/j.preteyeres.2006.05.001

Kelly A, Powis SH, Glynne R, Radley E, Beck S, Trowsdale J (1991) Second proteasome-related gene in the human MHC class II region. Nature 353:667-668. doi:10.1038/353667a0

Khanna KM, Bonneau RH, Kinchington PR, Hendricks RL (2003) Herpes simplex virus specific memory CD8 T cells are selectively activated and retained in latently infected sensory ganglia. Immunity 18:593-603. doi:10.1016/S1074-7613(03)00112-2

Kim JY, Mandarino A, Chao MV, Mohr I, Wilson AC (2012a) Transient reversal of episome silencing precedes VP16-dependent transcription during reactivation of latent HSV-1 in neurons. PLoS Pathog 8:e1002540. doi:10.1371/journal.ppat.1002540

Kim M, Osborne NR, Zeng W, Donaghy H, McKinnon K, Jackson DC, Cunningham AL (2012b) Herpes simplex virus antigens directly activate NK cells via TLR2, thus facilitating their presentation to CD4 T lymphocytes. J Immunol 188:4158-4170. doi:10.4049/ jimmunol.1103450

Knickelbein JE, Khanna KM, Yee MB, Baty CJ, Kinchington PR, Hendricks RL (2009) Noncytotoxic lytic granule mediated CD8 T cell 
inhibition of HSV-1 reactivation from neuronal latency. Science 322:268-271. doi:10.1126/science.1164164

Knipe DM, Cliffe A (2008) Chromatin control of herpes simplex virus lytic and latent infection. Nat Rev Microbiol 6:211-221. doi:10. 1038/nrmicro1794

Kobayashi M, Wilson AC, Chao MV, Mohr I (2012) Control of viral latency in neurons by axonal mTOR signaling and the 4E-BP translation repressor. Genes Dev 26:1527-1532. doi:10.1101/gad. 190157.112

Kodukula P, Liu T, Rooijen NV, Jager MJ, Hendricks RL (1999) Macrophage control of herpes simplex virus type 1 replication in the peripheral nervous system. J Immunol 162:2895-2905

Korsmeyer SJ, Wei MC, Saito M, Weiler S, Oh KJ, Schlesinger PH (2000) Pro-apoptotic cascade activates BID, which oligomerizes BAK or BAX into pores that result in the release of cytochrome c. Cell Death Differ 7:1166-1173. doi:10.1038/sj.cdd.4400783

Kramer MF, Coen DM (1995) Quantification of transcripts from the ICP4 and thymidine kinase genes in mouse ganglia latently infected with herpes simplex virus. J Virol 69:1389-1399

Kristie TM, Vogel JL, Sears AE (1999) Nuclear localization of the C1 factor (host cell factor) in sensory neurons correlates with reactivation of herpes simplex virus from latency. Proc Natl Acad Sci USA 96:1229-1233. doi:10.1073/pnas.96.4.1229

Kulms D, Zeise E, Pöppelmann B, Schwarz T (2002) DNA damage, death receptor activation and reactive oxygen species contribute to ultraviolet radiation-induced apoptosis in an essential and independent way. Oncogene 21:5844-5851. doi:10.1038/sj.onc. 1205743

Lafaille FG, Pessach IM, Zhang SY, Ciancanelli MJ, Herman M, Abhyankar A, Ying SW, Keros S, Goldstein PA, Mostoslavsky G, Ordovas-Montanes J, Jouanguy E, Plancoulaine S, Tu E, Elkabetz Y, Al-Muhsen S, Tardieu M, Schlaeger TM, Daley GQ, Abel L, Casanova JL, Studer L, Notarangelo LD (2012) Impaired intrinsic immunity to HSV-1 in human iPSC-derived TLR3-deficient CNS cells. Nature 491:769-773. doi:10.1038/nature11583

Latinovic-Golic S, Walch M, Sundstrom H, Dumrese C, Groscurth P, Ziegler U (2007) Expression, processing and transcriptional regulation of granulysin in short-term activated human lymphocytes. BMC Immunol 8:9. doi:10.1186/1471-2172-8-9

Leopardi R, Roizman B (1996) The herpes simplex virus major regulatory protein ICP4 blocks apoptosis induced by the virus or by hyperthermia. Proc Natl Acad Sci USA 93:9583-9587. doi:10. 1073/pnas.93.18.9583

Li S, Carpenter D, Hsiang C, Wechsler SL, Jones C (2010) Herpes simplex virus type 1 latency-associated transcript inhibits apoptosis and promotes neurite sprouting in neuroblastoma cells following serum starvation by maintaining protein kinase B (AKT) levels. J Gen Virol 91:858-866. doi:10.1099/vir.0.015719-0

Liu CC, Walsh CM, Young JD (1995) Perforin: structure and function. Immunol Today 16:194-201

Liu T, Khanna KM, Chen X, Fink DJ, Hendricks RL (2000) CD8(+) T cells can block herpes simplex virus type 1 (HSV-1) reactivation from latency in sensory neurons. J Exp Med 191:1459-1466. doi:10.1084/jem.191.9.1459

Lundberg P, Welander P, Han X, Cantin E (2003) Herpes simplex virus type 1 DNA is immunostimulatory in vitro and in vivo. J Virol 77:11158-11169. doi:10.1128/JVI.77.20.11158-11169.2003

Lynch F, Doherty PC, Ceredig R (1989) Phenotypic and functional analysis of the cellular response in regional lymphoid tissue during an acute virus infection. J Immunol 142:3592-3598

Mackay LK, Stock AT, Ma JZ, Jones CM, Kent SJ, Mueller SN, Heath WR, Carbone FR, Gebhardt T (2012) Long-lived epithelial immunity by tissue-resident memory T (TRM) cells in the absence of persisting local antigen presentation. Proc Natl Acad Sci USA 109:7037-7042. doi:10.1073/pnas.1202288109

Manning BD, Cantley LC (2007) AKT/PKB signaling: navigating downstream. Cell 129:1261-1274. doi:10.1016/j.cell.2007.06.009
Masopust D, Vezys V, Wherry EJ, Barber DL, Ahmed R (2006) Cutting edge: gut microenvironment promotes differentiation of a unique memory CD8 T cell population. J Immunol 176:2079-2083

Masopust D, Choo D, Vezys V, Wherry EJ, Duraiswamy J, Akondy R, Wang J, Casey KA, Barber DL, Kawamura KS, Fraser KA, Webby RJ, Brinkmann V, Butcher EC, Newell KA, Ahmed R (2010) Dynamic T cell migration program provides resident memory within intestinal epithelium. J Exp Med 207:553-564. doi:10.1084/jem. 20090858

Mastino A, Sciortino MT, Medici MA, Perri D, Ammendolia MG, Grelli S, Amici C, Pernice A, Guglielmino S (1997) Herpes simplex virus 2 causes apoptotic infection in monocytoid cells. Cell Death Differ 4:629-638. doi:10.1038/sj.cdd.4400289

Melchjorsen J (2012) Sensing herpes: more than toll. Rev Med Virol 22:106-121. doi:10.1002/rmv

Mellerick DM, Fraser NW (1987) Physical state of the latent herpes simplex virus genome in a mouse model system: evidence suggesting an episomal state. Virology 158:265-275. doi:10.1016/ 0042-6822(87)90198-X

Metkar SS, Wang B, Ebbs ML, Kim JH, Lee YJ, Raja SM, Froelich CJ (2003) Granzyme B activates procaspase-3 which signals a mitochondrial amplification loop for maximal apoptosis. J Cell Biol 160:875-885. doi:10.1083/jcb.200210158

Meurs E, Chong K, Galabru J, Thomas NS, Kerr IM, Wiliams BR, Hovanessian AG (1990) Molecular cloning and characterization of the human double-stranded RNA-activated protein kinase induced by interferon. Cell 62:379-390. doi:10.1016/0092-8674(90)90374-N

Miles DH, Thakur A, Cole N, Willcox MDP (2007) The induction and suppression of the apoptotic response of HSV-1 in human corneal epithelial cells. Invest Ophthalmol Vis Sci 48:789-796. doi:10. 1167/iovs.06-0609

Mott K, Brick DJ, Van Rooijen N, Ghiasi H (2007) Macrophages are important determinants of acute ocular HSV-1 infection in immunized mice. Invest Ophthalmol Vis Sci 48:5605-5615. doi:10.1167/ iovs.07-0894

Motyka B, Korbutt G, Pinkoski MJ, Heibein JA, Caputo A, Hobman M, Barry M, Shostak I, Sawchuk T, Holmes CF, Gauldie J, Bleackley RC (2000) Mannose 6-phosphate/insulin-like growth factor II receptor is a death receptor for granzyme B during cytotoxic T cellinduced apoptosis. Cell 103:491-500. doi:10.1016/S0092-8674(00) 00140-9

Mueller SN, Jones CM, Chen W, Kawaoka Y, Castrucci MR, Heath WR, Carbone FR (2003) The early expression of glycoprotein B from herpes simplex virus can be detected by antigen-specific CD8+ T cells. J Virol 77:2445-2451. doi:10.1128/JVI.77.4.2445

Nicola AV, Straus SE (2004) Cellular and viral requirements for rapid endocytic entry of herpes simplex virus. J Virol 78:7508-7517. doi:10.1128/JVI.78.14.7508-7517.2004

Nicola AV, Hou J, Major EO, Straus SE (2005) Herpes simplex virus type 1 enters human epidermal keratinocytes, but not neurons, via a $\mathrm{pH}-$ dependent endocytic pathway. J Virol 79:7609-7616. doi:10.1128/ JVI.79.12.7609

Oh M-J, Akhtar J, Desai P, Shukla D (2010) A role for heparan sulfate in viral surfing. Biochem Biophys Res Commun 391:176-181. doi:10. 1016/j.bbrc.2009.11.027

Okouchi M, Ekshyyan O, Maracine M, Aw TY (2007) Neuronal apoptosis in neurodegeneration. Antioxid Redox Signal 9:1059-1096. doi:10.1089/ars.2007.1511

Oosten LE, Koppers-Lalic D, Blokland E, Mulder A, Ressing ME, Mutis T, van Halteren AG, Wiertz EJ, Goulmy E (2007) TAP-inhibiting proteins US6, ICP47 and UL49.5 differentially affect minor and major histocompatibility antigen-specific recognition by cytotoxic $\mathrm{T}$ lymphocytes. Int Immunol 19:1115-1122. doi:10.1093/intimm/ dxm082

Orr MT, Mathis MA, Lagunoff M, Sacks JA, Wilson CB (2008) CD8 T cell control of HSV reactivation from latency is abrogated by viral 
inhibition of MHC class I. Cell Host Microbe 2:172-180. doi:10. 1016/j.chom.2007.06.013

Oxman MN, Levin MJ, Johnson GR, Schmader KE, Straus SE, Gelb LD, Arbeit RD, Simberkoff MS, Gershon AA, Davis LE, Weinberg A, Boardman KD, Williams HM, Zhang JH, Peduzzi PN, Beisel CE, Morrison VA, Guatelli JC, Brooks PA, Kauffman CA, Pachucki CT, Neuzil KM, Betts RF, Wright PF, Griffin MR, Brunell P, Soto NE, Marques AR, Keay SK, Goodman RP, Cotton DJ, Gnann JW Jr, Loutit J, Holodniy M, Keitel WA, Crawford GE, Yeh SS, Lobo Z, Toney JF, Greenberg RN, Keller PM, Harbecke R, Hayward AR, Irwin MR, Kyriakides TC, Chan CY, Chan IS, Wang WW, Annunziato PW, Silber JL, Shingles Prevention Study Group (2005) A vaccine to prevent herpes zoster and postherpetic neuralgia in older adults. $\mathrm{N}$ Engl $\mathrm{J}$ Med 352:2271-2284. doi:10.1056/ NEJMoa051016

Paludan SR, Bowie AG, Horan KA, Fitzgerald KA (2011) Recognition of herpesviruses by the innate immune system. Nat Rev Immunol 11:143-154. doi:10.1038/nri2937

Pereira RA, Simon MM, Simmons A (2000) Granzyme A, a noncytolytic component of CD8 $(+)$ cell granules, restricts the spread of herpes simplex virus in the peripheral nervous systems of experimentally infected mice. J Virol 74:1029-1032. doi:10.1128/JVI.74.2.10291032.2000

Peri P, Nuutila K, Vuorinen T, Saukko P, Hukkanen V (2011) Cathepsins are involved in virus-induced cell death in ICP4 and Us3 deletion mutant herpes simplex virus type 1 -infected monocytic cells. J Gen Virol 92:173-180. doi:10.1099/vir.0.025080-0

Pichlmair A, Schulz O, Tan C-P, Rehwinkel J, Kato H, Takeuchi O, Akira S, Way M, Schiavo G, Reis E, Sousa C (2009) Activation of MDA5 requires higher-order RNA structures generated during virus infection. J Virol 83:10761-10769. doi:10.1128/JVI.00770-09

Pinkoski MJ, Waterhouse NJ, Heibein JA, Wolf BB, Kuwana T, Goldstein JC, Newmeyer DD, Bleackley RC, Green DR (2001) Granzyme B-mediated apoptosis proceeds predominantly through a Bcl-2-inhibitable mitochondrial pathway. J Biol Chem 276:12060-12067. doi:10.1074/jbc.M009038200

Pollara G, Speidel K, Samady L, Rajpopat M, McGrath Y, Ledermann J, Coffin RS, Katz DR, Chain B (2003) Herpes simplex virus infection of dendritic cells: balance among activation, inhibition, and immunity. J Infect Dis 187:165-178. doi:10.1086/367675

Pollara G, Jones M, Handley ME, Rajpopat M, Kwan A, Coffin RS, Foster G, Chain B, Katz DR (2004) Herpes simplex virus type-1induced activation of myeloid dendritic cells: the roles of virus cell interaction and paracrine type I IFN secretion. J Immunol 173:41084119

Rahn E, Petermann P, Hsu MJ, Rixon FJ, Knebel-Mörsdorf D (2011) Entry pathways of herpes simplex virus type 1 into human keratinocytes are dynamin- and cholesterol-dependent. PLoS One 6:e25464. doi:10.1371/journal.pone.0025464

Ramachandran S, Davoli KA, Yee MB, Hendricks RL, Kinchington PR (2010) Delaying the expression of herpes simplex virus type 1 glycoprotein $\mathrm{B}(\mathrm{gB})$ to a true late gene alters neurovirulence and inhibits the gB-CD8+ T-cell response in the trigeminal ganglion. $\mathrm{J}$ Virol 84:8811-8820. doi:10.1128/JVI.00496-10

Ravetch JV (2000) Immune inhibitory receptors. Science 290:84-89. doi: $10.1126 /$ science. 290.5489 .84

Reading PC, Whitney PG, Barr DP, Wojtasiak M, Mintern JD, Waithman J, Brooks AG (2007) IL-18, but not IL-12, regulates NK cell activity following intranasal herpes simplex virus type 1 infection. J Immunol 179:3214-3221

Roizman B, Knipe DM, Whitley RJ (2007) Herpes simplex viruses. In: Knipe D, Howley PM (eds) Fields' virology, 5th edn. Lippincott Williams \& Wilkins, Philadelphia, pp 2501-2602

Roizman B, Zhou G, Du T (2011) Checkpoints in productive and latent infections with herpes simplex virus 1: conceptualization of the issues. J Neurovirol 17:512-517. doi:10.1007/s13365-011-0058-x
Rowley AH, Whitley RJ, Lakeman FD, Wolinksy SM (1990) Rapid detection of herpes-simplex-virus DNA in cerebrospinal fluid of patients with herpes simplex encephalitis. Lancet 1:440-441. doi:10.1016/0140-6736(90)90667-T

Sanfilippo CM, Blaho JA (2006) ICP0 gene expression is a herpes simplex virus type 1 apoptotic trigger. J Virol 80:6810-6821. doi:10.1128/JVI.00334-06

Satoh T, Arii J, Suenaga T, Wang J, Kogure A, Uehori J, Arase N, Shiratori I, Tanaka S, Kawaguchi Y, Spear PG, Lanier LL, Arase $\mathrm{H}$ (2008) PILRalpha is a herpes simplex virus-1 entry coreceptor that associates with glycoprotein B. Cell 132:935-944. doi:10.1016/ j.cell.2008.01.043

Schlee M, Roth A, Hornung V, Hagmann CA, Wimmenauer V, Barchet W, Coch C, Janke M, Mihailovic A, Wardle JS, Kato H, Kawai T, Poeck H, Fitzgerald KA, Takeuchi O, Akira S, Teschl T, Latz E, Ludwig J, Hartmann G (2009) Recognition of $5^{\prime}$ triphosphate by RIG-I helicase requires short blunt doublestranded RNA as contained in panhandle of negative-strand virus. Immunity 31:25-34. doi:10.1016/j.immuni.2009.05.008

Sciortino MT, Medici MA, Marino-Merlo F, Zaccaria D, GuiffreCuculletto M, Venuti A, Grelli BP, Mastino A (2008) Involvement of gD/HVEM interaction in NF-kB-dependent inhibition of apoptosis by HSV-1 gD. Biochem Pharmacol 76:1522-1532. doi:10.1016/ j.bcp.2008.07.030

Sears AE, Hukkanen V, Labow MA, Levine AJ, Roizman B (1991) Expresssion of the herpes simplex virus 1 alpha transinducing factor (VP16) does not induce reactivation of latent virus or prevent the establishment of latency in mice. J Virol 65:2929-2935

Sen J, Liu X, Roller R, Knipe DM (2013) Herpes simplex virus US3 tegument protein inhibits Toll-like receptor 2 signaling at or before TRAF6 ubiquitination. Virology 439:65-73. doi:10.1016/j.virol. 2013.01.026

Shah SS, Wood SM, Luan X, Ratner AJ (2010) Decline in varicellarelated ambulatory visits and hospitalizations in the United States since routine immunization against varicella. Pediatr Infect Dis J 29:199-204. doi:10.1097/INF.0b013e3181bbf2a0

Shen W, Sa E, Silva M, Jaber T, Vitvitskaia O, Li S, Henderson G, Jones C (2009) Two small RNAs encoded within the first 1.5 kilobases of the herpes simplex virus type 1 latencyassociated transcript can inhibit productive infection and cooperate to inhibit apoptosis. J Virol 83:9131-9139. doi:10. 1128/JVI.00871-09

Sheridan BS, Khanna KM, Frank GM, Hendricks RL (2006) Latent virus influences the generation and maintenance of CD8+ T cell memory. J Immunol 177:8356-8364

Sheridan BS, Cherpes TL, Urban J, Kalinski P, Hendricks RL (2009) Reevaluating the CD8 T-cell response to herpes simplex virus type 1: involvement of CD8 $\mathrm{T}$ cells reactive to subdominant epitopes. J Virol 83:2237-2245. doi:10.1128/ JVI.01699-08

Shin H, Iwasaki A (2012) A vaccine strategy that protects against genital herpes by establishing local memory T cells. Nature 491:463-467. doi:10.1038/nature11522

Shukla D, Spear PG (2001) Herpesviruses and heparan sulfate: an intimate relationship in aid of viral entry. J Clin Invest 108:503-510. doi:10.1172/JCI13799

Shukla D, Liu J, Blaiklock P, Shworak NW, Bai X, Esko JD, Cohen GH, Eisenberg RJ, Rosenberg RD, Spear PG (1999) A novel role for 3O-sulfated heparan sulfate in herpes simplex virus 1 entry. Cell 99:13-22. doi:10.1016/S0092-8674(00)80058-6

Shukla ND, Tiwari V, Valyi-Nagy T (2012) Nectin-1-specific entry of herpes simplex virus 1 is sufficient for infection of the cornea and viral spread to the trigeminal ganglia. Mol Vis 18:2711-2716

Sijts EJAM, Kloetzel PM (2011) The role of the proteasome in the generation of MHC class I ligands and immune responses. Cell Mol Life Sci 68:1491-1502. doi:10.1007/s00018-011-0657-y 
Simpson SA, Manchak MD, Hager EJ, Krummenacher C, Whitbeck JC, Levin MJ, Freed CR, Wilcox CL, Cohen GH, Eisenberg RJ, Pizer LI (2005) Nectin-1/HveC Mediates herpes simplex virus type 1 entry into primary human sensory neurons and fibroblasts. J Neurovirol 11:208-218. doi:10.1080/13550280590924214

Skalsky RL, Cullen BR (2010) Viruses, microRNAs, and host interactions. Annu Rev Microbiol 64:123-141. doi:10.1146/annurev.micro.112408. 134243

Smith G (2012) Herpesvirus transport to the nervous system and back again. Annu Rev Microbiol 66:153-176. doi:10.1146/annurevmicro-092611-150051

Smith GA, Gross SP, Enquist LW (2001) Herpesviruses use bidirectional fast-axonal transport to spread in sensory neurons. Proc Natl Acad Sci 98:3466-3470. doi:10.1073/pnas.061029798

Strom T, Frenkel N (1987) Effects of herpes simplex virus on mRNA stability. J Virol 61:2198-2207

Stuart PM, Summers B, Morris JE, Morrison LA, Leib DA (2004) CD8(+) T cells control corneal disease following ocular infection with herpes simplex virus type 1. J Gen Virol 85:2055-2063. doi:10. 1099/vir.0.80049-0

Su YH, Moxley MJ, Ng AK, Lin J, Jordan R, Fraser NW, Block TM (2002) Stability and circularization of herpes simplex virus type 1 genomes in quiescently infected PC12 cultures. J Gen Virol 83:2943-2950

Tang VA, Rosenthal KL (2010) Intravaginal infection with herpes simplex virus type-2 (HSV-2) generates a functional effector memory $\mathrm{T}$ cell population that persists in the murine genital tract. J Reprod Immunol 87:39-44. doi:10.1016/j.jri.2010.06.155

Thompson RL, Sawtell NM (2011) The herpes simplex virus type 1 latency associated transcript locus is required for the maintenance of reactivation competent latent infections. J Neurovirol 17:552558. doi:10.1007/s13365-011-0071-0

Tissari J, Sirén J, Meri S, Julkunen I, Matikainen S (2005) IFN-alpha enhances TLR3-mediated antiviral cytokine expression in human endothelial and epithelial cells by up-regulating TLR3 expression. J Immunol 174:4289-4294

Tiwari V, Clement C, Scanlan PM, Kowlessur D, Yue BY, Shukla D (2005) A role for herpesvirus entry mediator as the receptor for herpes simplex virus 1 entry into primary human trabecular meshwork cells. J Virol 79:13173-13179. doi:10.1128/JVI.79.20.1317313179.2005

Tomas MI, Kucić N, Mahmutefendić H, Blagojevic G, Lucin P (2010) Murine cytomegalovirus perturbs endosomal trafficking of major histocompatibility complex class I molecules in the early phase of infection. J Virol 84:11101-11112. doi:10.1128/JVI.00988-10

Umbach JL, Kramer MF, Jurak I, Karnowski HW, Coen DM, Cullen BR (2008) MicroRNAs expressed by herpes simplex virus type 1 during latent infection regulate viral mRNAs. Nature 454:780-783. doi:10. 1038/nature07103

Umbach JL, Nagel MA, Cohrs RJ, Gilden DH, Cullen BR (2009) Analysis of human alphaherpesvirus microRNA expression in latently infected human trigeminal ganglia. J Virol 83:10677-10683. doi:10.1128/JVI.01185-09

Verjans GM, Hintzen RQ, van Dun JM, Poot A, Milikan JC, Laman JD, Langerak AW, Kinchington PR, Osterhaus AD (2007) Selective retention of herpes simplex virus-specific $\mathrm{T}$ cells in latently infected human trigeminal ganglia. Proc Natl Acad Sci USA 104:34963501. doi:10.1073/pnas.0610847104

Voskoboinik I, Thia MC, Fletcher J, Ciccone A, Browne K, Smyth MJ, Trapani JA (2005) Calcium-dependent plasma membrane binding and cell lysis by perforin are mediated through its $\mathrm{C} 2$ domain: a critical role for aspartate residues $429,435,483$, and 485 but not 491. J Biol Chem 280:8426-8434. doi:10.1074/jbc.M413303200
Wagner EK, Devi-Rao G, Feldman LT, Dobson AT, Zhang YF, Flanagan WM, Stevens JG (1988) Physical characterization of the herpes simplex virus latency-associated transcript in neurons. J Virol 62:1194-1202

Wakim LM, Woodward-Davis A, Bevan MJ (2010) Memory T cells persisting within the brain after local infection show functional adaptations to their tissue of residence. Proc Natl Acad Sci USA 107:1787217879. doi:10.1073/pnas.1010201107/-/DCSupplemental.www.pnas. org/cgi/doi/10.1073/pnas.1010201107

Wakim LM, Woodward-Davis A, Liu R, Hu Y, Villadangos J, Smyth G, Bevan MJ (2012) The molecular signature of tissue resident memory CD8 T cells isolated from the brain. J Immunol 189:3462-3471. doi:10.4049/jimmunol.1201305

Wallach D, Fellous M, Revel M (1982) Preferential effect of gamma interferon on the synthesis of HLA antigens and their mRNAs in human cells. Nature 299:833-836. doi:10.1038/299833a0

Waterhouse NJ, Sedelies KA, Sutton VR, Pinkoski MJ, Thia KY, Johnstone R, Bird PI, Green DR, Trapani JA (2006a) Functional dissociation of DeltaPsim and cytochrome $\mathrm{c}$ release defines the contribution of mitochondria upstream of caspase activation during granzyme B-induced apoptosis. Cell Death Differ 13:607-618. doi:10.1038/sj.cdd.4401772

Waterhouse NJ, Sedelies KA, Trapani JA (2006b) Role of Bid-induced mitochondrial outer membrane permeabilization in granzyme Binduced apoptosis. Immunol Cell Biol 84:72-78. doi:10.1111/j. 1440-1711.2005.01416.x

Weber F, Wagner V, Rasmussen SB, Hartmann R, Paludan SR (2006) Double-stranded RNA is produced by positive-strand RNA viruses and DNA viruses but not in detectable amounts by negative-strand RNA viruses. J Virol 80:5059-5064. doi:10.1128/JVI.80.10.50595064.2006

Williams NS, Klem J, Puzanov IJ, Sivakumar PV, Schatzle JD, Bennett M, Kumar V (1998) Natural killer cell differentiation: insights from knockout and transgenic mouse models and in vitro systems. Immunol Rev 165:47-61. doi:10.1111/j.1600-065X.1998.tb01229.x

Xaus J, Cardó M, Valledor AF, Soler C, Lloberas J, Celada A (1999) Interferon gamma induces the expression of $\mathrm{p} 21$ waf- 1 and arrests macrophage cell cycle, preventing induction of apoptosis. Immunity 11:103-113

Xu F, Sternberg MR, Kottiri BJ, McQuillan GM, Lee FK, Nahmias AJ, Berman SM, Markowitz LE (2006) Trends in herpes simplex virus type 1 and type 2 seroprevalence in the United States. JAMA 296:964-973. doi:10.1001/jama.296.8.964

Yang L, Voytek CC, Margolis TP (2000) Immunohistochemical analysis of primary sensory neurons latently infected with herpes simplex virus type 1. J Virol 74:209-217. doi:10.1128/JVI.74.1.209-217. 2000

York IA, Roop C, Andrews DW, Riddell SR, Graham FL, Johnson DC (1994) A cytosolic herpes simplex virus protein inhibits antigen presentation to CD8+ T lymphocytes. Cell 77:525-535. doi:10. 1016/0092-8674(94)90215-1

Yoshida A, Koide Y, Uchijima M, Yoshida TO (1994) IFN-gamma induces IL-12 mRNA expression by a murine macrophage cell line, J774. Biochem Biophys Res Commun 198:857-861. doi:10.1006/ bbrc.1994.1122

Zhang SY, Jouanguy E, Ugolini S, Smahi A, Elain G, Romero P, Segal D, Sancho-Shimizu V, Lorenzo L, Puel A, Picard C, Chapgier A, Plancoulaine $\mathrm{S}$, Titeux $\mathrm{M}$, Cognet $\mathrm{C}$, von Bernuth $\mathrm{H}, \mathrm{Ku} \mathrm{CL}$, Casrouge A, Zhang XX, Barreiro L, Leonard J, Hamilton C, Lebon P, Héron B, Vallée L, Quintana-Murci L, Hovnanian A, Rozenberg F, Vivier E, Geissmann F, Tardieu M, Abel L, Casanova JL (2007) TLR3 deficiency in patients with herpes simplex encephalitis. Science 317:1522-1527. doi:10.1126/science. 1139522 